\title{
NEOGENE CALCAREOUS NANNOFOSSILS FROM SAN JOSÉ ISLAND, BAJA CALIFORNIA SUR, MEXICO
}

\author{
AURORA A. JIMÉNEZ-MENDOZA \\ Programa de Posgrado en Ciencias de la Tierra, Instituto de Geología, Universidad Autónoma de México. \\ Circuito Exterior C.U., Coyoacán, 04510. CdMex., Mexico. \\ kfepara3_trp@hotmail.com \\ ANA LUISA CARREÑO \\ Instituto de Geología, Universidad Autónoma de México. Circuito Exterior C.U., Coyoacán, 04510.Cd Mex., Mexico. \\ anacar@unam.mx
}

\author{
ADRIANA Y. MIRANDA-MARTÍNEZ \\ Programa de Posgrado en Ciencias de la Tierra, Instituto de Geología, Universidad Autónoma de Mexico. \\ Circuito Exterior C.U., Coyoacán, 04510. CdMex., Mexico. \\ amiranda@ciencias.unam.mx \\ JORGE LEDESMA-VÁZQUEZ \\ Facultad de Ciencias Marinas, Universidad Autónoma de Baja California, Apartado Postal 453, \\ Ensenada 22800, Baja California, Mexico. \\ ledesma@uabc.edu.mx
}

\begin{abstract}
A study of calcareous nannofossils was carried out in two sedimentary columns from the Palma Sola Basin, San José Island, Baja California Sur, Mexico, in order to establish the age of these deposits and to place them in a chronostratigraphic context within the evolution of the Gulf of California. A total of 66 species were identified and based on the presence of small Gephyrocapsa, Reticulofenestra minuta, $R$. minutula, $R$. haqii, Pseudoemiliania lacunosa and P. ovate, an age of $\approx 3.6$ Ma for Palma Sola I and at least for most part of the Palma Sola II equivalent to the standard NN15 Reticulofenestra pseudoumbilica Zone is assigned. The top of the Palma Sola II column does not contain reticulofenestrids. If its absence is stratigraphic, a younger age could be inferred; however, considering also the absence of zonal indicators, is tentatively, at least $\approx 3.6 \mathrm{Ma}$. On the basis of the abundance of Coccolithus pelagicus s.l., small to medium Reticulofenestra spp., and small Gephyrocapsa and Helicosphaera spp., a paleoenvironment influenced by coastal upwelling is inferred.
\end{abstract}

Keywords: Neogene, nannofossils, Foraminifera, Gulf of California, Mexico.

RESUMO - Um estudo de nanofósseis calcários foi realizado em duas colunas sedimentares da Bacia de Palma Sola, na ilha de San Jose, Baja California Sur, México, a fim de estabelecer a idade desses depósitos e colocá-los em um contexto cronoestratigráfico dentro da evolução do Golfo da Califórnia. Foram identificadas 66 espécies e com base na presença de Gephyrocapsa de tamanho reduzido, Reticulofenestra minuta, R. minutula, R. haqii, Pseudoemiliania lacunosa e P. ovata, é atribuído às colunas Palma Sola I e a base e parte média da coluna Palma Sola II, uma idade de pelo menos 3.6 Ma, equivalente a zona padrão NN15 de Reticulofenestra pseudoumbilica. O topo da coluna Palma Sola II não contém reticulofenéstridos. Se a sua ausência é estratigráfica, ela poderia ser mais jovem; no entanto, a falta de indicadores zonais não permite uma atribuição de idade, a qual é tentativamente considerada de pelo menos 3,6 Ma. Com base na abundância de Coccolithus pelagicus s.l, pequenos a médios Reticulofenestra spp., pequenos Gephyrocapsa e Helicosphaera spp., é inferido um paleoambiente influenciado pela ressurgência costeira.

Palavras-chave: Neógeno, nanofósseis, Foraminifera, Golfo de Califórnia, México. 


\section{INTRODUCTION}

The presence of the calcareous nannofossils in Jurassic, Cretaceous, and Cenozoic marine sequences in Mexico has been largely documented in several unpublished reports by PEMEX (Petróleos Mexicanos). Nevertheless, published papers dealing with paleontological aspects are scarce. Specifically for Baja California Coleman (1979), Carreño (1992a,b) and García-Cordero \& Carreño (2009) can be mentioned. In several reports, dealing with the Neogene tectonic evolution of the Gulf of California is a common practice to report a checklist of microfossils species (Colleta \& Angelier, 1981; Vázquez-Hernández et al., 1996; Martín-Barajas et al., 2001; Dorsey et al., 2002; Umhoefer et al., 2007; McDougall, 2008; Gómez-Sánchez, 2013; Schwennicke et al., 2017). These microfossils are utilized to provide a chronostratigraphic framework that allows establishing the time of basin formation and its paleoceanographic configuration. However, this information is irrelevant when the exact distribution and abundance of the species is not known and when it is not possible to know the repository of the specimens. The more reliable research using the calcareous nannofossils for biostratigraphic purposes in the Neogene of Baja California was done by Piña-Arce (2010), but unfortunately it remains unpublished.

An extensive project dealing with the marine evolution of the Gulf of California is undergoing and the calcareous microfossils have been documented throughout the Neogene key-localities. This paper document the presence of calcareous nannofossils throughout two sedimentary columns cropping out in San José Island, Baja California Sur, México, in order to establish the age of the deposits based on the species assemblages.

\section{Previous studies}

Macrofossils in San José Island were noted during the California Academy of Science Expeditions in 1921 and 1923, which were later studied by Hanna \& Hertlein (1927). The finding of the elephantid Rhyncotherium in the Pleistocene (Applegate \& Carranza-Castañeda, 1993) was interpreted as evidence that during this time San José Island was emerged and attached to the peninsula. In a preliminary mapping of the island reported by Puy-Alquiza (1992), a regional basement constituted by Cretaceous granitic rocks is covered in the southern portion of the island by volcanic rocks of the Oligocene-Miocene Comondú Group and younger sedimentary units. To the north, the Palma Sola and Punta Colorado basins develop on the granitic rocks basement that is unconformably overlyied by Neogene marine deposits. According with Umhoefer et al. (2007), there are eight sedimentary facies associations overlying the granitic rocks as part of four sequences, described from bottom to top as: Sequence 1, conglomerate and sandstone overlaid by conglomerate interpreted as fluvial to alluvial fan; Sequence
2, massive sparsely shelly sandstone (bay), shelly sandstone and conglomerate (delta, nearshore), conglomerate and sandstone (fluvial) and conglomerate (alluvial fan); Sequence 3 , mudstone (outer shelf to upper slope), cross-bedded shelly sandstone (Gilbert deltas), bedded sandstone and calcarenite (inner shelf) bedded sandstone (inner shelf), massive sparsely shelly sandstone (bay), shelly sandstone (tidal near shore) shelly sandstone and conglomerate (delta, nearshore) conglomerate (alluvial fan); and Sequence 4, calcarenite (shallow marine), shelly conglomerate (gravel beach) and conglomerate and sandstone (fluvial). An important characteristic overlooked in previous reports is the presence of the thin layers of shelly biocalcarenite in some parts of the columns, as well as that the massive shelly sandstone is the result of gravity flows processes affecting older units, being underwater all the time.

According with Umhoefer et al. (2007), an ${ }^{40} \mathrm{Ar} /{ }^{39} \mathrm{Ar}$ dating in a tuffaceous sandstone in the western embayment of Punta Colorada (lower sequence 2 interpreted as deposited in shallow water) yielded a $3.6 \pm 05-3.1$ Ma age. A checklist of the microfossils recovered from the upper sequence 3 (middle to lower upper part of the La Gata mudstone) has been published by Umhoefer et al. (2007), giving a latest Pliocene/earliest Pleistocene age (2.4-2.5 Ma) for this part of the sequence, interpreted as deposited under an oscillating oxygenated to oxygen-deficient bottom water in an upper slope environment.

\section{MATERIAL AND METHODS}

San José Island is located $4.61 \mathrm{~km}$ off North La Paz Bay $\left(24^{\circ} 52^{\prime}\right.$ and $25^{\circ} 06^{\prime} \mathrm{N}-110^{\circ} 43^{\prime} \mathrm{W}$ and $\left.110^{\circ} 35^{\prime} \mathrm{W}\right)$ Baja California Sur, Mexico (Figure 1). It has an area of approximately $187.16 \mathrm{~m}^{2}$ (Gonzáles-Bourillon, 1988). Two sedimentary columns corresponding to the upper part of the Sequence 3 (La Gata mudstone) of Umhoefer et al. (2007) were measured in the Palma Sola Basin using a Brunton compass and a Jacob Staff. Forty-nine samples were collected: column Palma Sola I with a total thickness of $518.7 \mathrm{~cm}$ (Loc. IGM-3938,10 samples; $25^{\circ} 03^{\prime} 38.3^{\prime \prime} \mathrm{N}-110^{\circ} 40^{\prime} 51.5^{\prime \prime} \mathrm{W}$ ), and column Palma Sola II with a total thickness of $3708.5 \mathrm{~cm}$ (Loc. IGM-3939; 39 samples; 2503'43”'N 11040'57.17' W; Figure 2).

Smear slides were prepared according to Perch-Nielsen (1985)'s method. They were observed to identify and tabulate the calcareous nannofossil content. Sediment equivalent to the head of a pin was placed over a $76 \times 26$ $\mathrm{mm}$ microscope slides and dispersed with one milliliter of deionized water over it, using a toothpick. It was dried placing the slide on a hot plate. Once cooled, a mounting medium (Canada balsam) was applied to a square coverglass and then cooked in a hot-plate for half minute. Two smear slides per sample were prepared. Observation was made under a polarized microscope (Olympus model BH- 


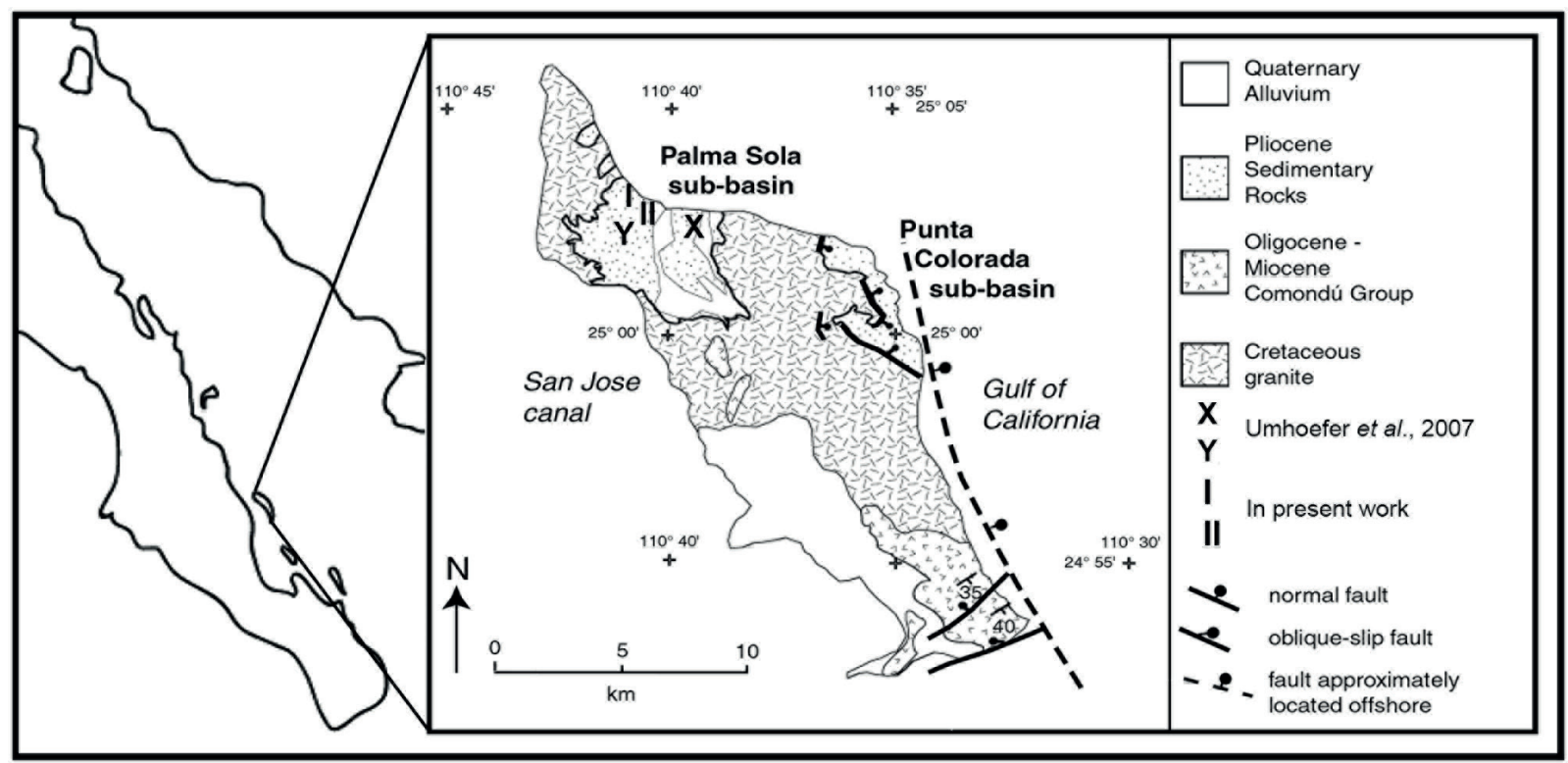

Figure 1. San José Island, Baja California Sur, Mexico. Location of the two columns sampled throughout the La Gata mudstone I and II. Geologic features from Puy-Alquiza (1992) modified by Umhoefer et al. (2007).
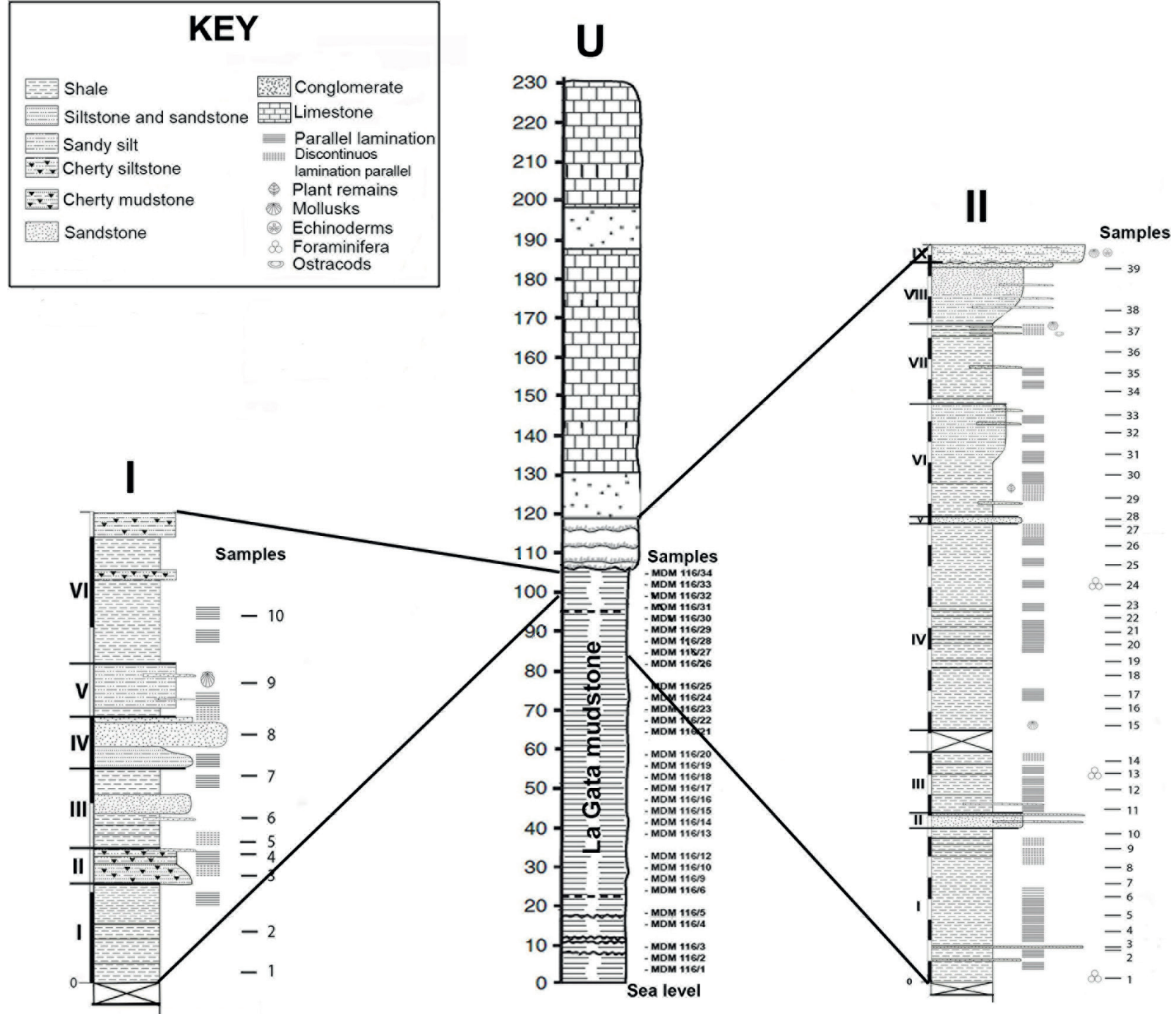

Figure 2. Columns (I and II) sampled throughout the La Gata mudstone and columns (X and Y) by Umhoefer et al. (2007) in Palma Sola subbasin in San José Island, Baja California Sur, Mexico. 
2) at 100X immersion with crossed Nichols $40 \mathrm{X}$ and $100 \mathrm{X}$ achromatic objectives. In some cases, a $1 \frac{2}{2} \lambda$ gypsum plate with a $30 \mathrm{~m}$ wavelength delay was used to facilitate the observation and identification of non birefringent nannoliths and discoasterids. Species identification follows the criteria of several authors (Bramlette \& Sullivan, 1961; Bramlette \& Wilcoxon, 1967; Bukry, 1971; Perch-Nielsen, 1977, 1985; Sherwood et al., 2002; Young et al., 2014). Micrographs were obtained using a Carl Zeiss AxioCam of 1.4 megapixels and the AxioVision 4.8 software.

The taxonomic identification was corroborated when necessary and possible under the Scanning Electron Microscope (SEM) JEOL: JSM 6360LV using an adapted technique (Perch-Nielsen, 1985; Bollmann et al., 2002), where the water with the cleaned coccoliths is filtered through a cellulose membrane (Millipore $25 \mathrm{~mm}$ in diameter and 0.45 $\mu \mathrm{m}$ pore) and rinsed with Milli-Q water. Then, it is allowed to dry at room temperature and coated with gold using a thin palladium ionizer JFC-1100 JEOL. SEM was particularly useful for the study of the genus Gephyrocapsa $(<3 \mu \mathrm{m})$ due to the diverse morphologies that exhibited the specimens. Some specimens might be referred as G. aperta, G. muellerae/ margereli or to other species; nevertheless, we considered not practical to identify them by light microscopy, and they are simply referred to the informal category small Gephyrocapsa and the different morphotypes illustrated. In addition, the SEM was important to discriminate the specimens belonging to the genus Pontosphaera from those belonging to Scyphosphaera. In Recent sediments it is relatively easy to distinguish one from another genus, but both genera produce muroliths and for this reason these are assigned in the fossil record to Pontosphaera whereas the lopadoliths are assigned to Scyphosphaera.

Due to dilution, the calcareous nannofossils at both localities were sparse and scarce and it was not possible to make a quantitative analysis following the standard methodology (Perch-Nielsen, 1985). Nevertheless, smear slides with concentrate residue were prepared and their abundance was tabulated using the following criteria:

$\mathrm{R}=$ rare: $1-16$ specimens by observed transect at X1000;

$\mathrm{F}=$ few: $17-600$ specimens by observed transect at X1000;

$\mathrm{C}=$ common: 601-6000 specimens by observed transect at X1000;

$\mathrm{A}=$ abundant: $>6000$ specimens by observed transect at X1000

Digital files of the identified species (IGMD 95 Mi-IGMD $160 \mathrm{Mi}$ ) and the smear slides from each sample (IGML 150 Mi-IGML $247 \mathrm{Mi}$ ) were housed in the micropaleontological collection of the Museo de Paleontología, Instituto de Geología (UNAM).

\section{RESULTS}

Two sedimentary columns were measured and sampled in the Palma Sola Basin in the upper part of Sequence 3 named the La Gata mudstone of Umhoefer et al. (2007). The lithic attributes of both columns are shown in Figure 2, as well as the columns of Umhoefer et al. (2007).
The Column I was divided into six units. The base is not exposed and its lower unit is composed by massive shale followed by interbedded mudstone and fine sandstone with chert and fine-grained sandstone lenses. Upper section siltstone and medium-grained sandstone grading to finegrained sandstone are present overlain by siltstone and lenses of fine-grained sandstone with fragments of mollusks; the top consists of laminated shale and upper contact nonconformable. Calcareous nannofossils and foraminifers present.

The Column II is a repetitive sequence of shales interbedded with fine, medium and coarse grain sandstones. Most of the units contain foraminifera and calcareous nannofossils. Total thickness of this amalgamated part of the column is $4,233 \mathrm{~cm}$. At the top of the column a coarse-grained biocalcarenite $90.9 \mathrm{~cm}$ thick with remains of mollusks and echinoderms rest unconformably. This unit was described as massive sparsely shelly sandstone by Umhoefer et al. (2017). The contact with the previous unit is not conformable due to erosion, associated to a possible gravity flow, and it is shown in the field as unconformable both laterally and on the base of the flow.

Sixty-six species were identified. Thirty-seven species were present in both sedimentary columns. All the species here reported has been extensively described and illustrated by other authors and for this reason only a checklist in alphabetical order is included; the most conspicuous taxa are illustrated in Figures 3-7.

The most employed Neogene Standard Zonal Schemes for the low latitude regions using the stratigraphic record of calcareous nannofossils species are Martini (1971), Martini \& Worsley (1971), Bukry (1973a, 1975) and Okada \& Bukry (1980). In the Gulf of California, ages based on this group have been established using two of them (Martini, 1971; Bukry, 1973a); nevertheless, many zones have not been recognized due to the absence of several index species. Therefore, in this paper we use as far as possible the classical zonal scheme of Bukry (1975), as well as the updated stratigraphic range of some species used by several authors (Okada \& Bukry, 1980; Perch-Nielsen, 1985; Young \& Bown, 1997; Bown, 1998). The taxonomic checklist includes the consensual stratigraphic ranges for species recorded in both columns (Appendix 1).

In Palma Sola I, samples 3, 5 and 7 do not contain calcareous nannofossils, samples 6,8 and 9 have common abundances and good preservation, while in the rest of the samples the nannofossils are rare to few and moderately preserved, with evident signs of dissolution and overgrowth (Figure 8). A total of forty-three species were identified, being the most conspicuous and with common abundances Coccolithus pelagicus, Gephyrocapsa small, Helicosphaera sellii and Reticulofenestra haqii. Also, some reworked Miocene species were observed: Coronocyclus nitescens, Discoaster formosus, and Helicosphera burkei.

The calcareous nannofossils have a highly erratic distribution throughout. At the base, none of the recorded 


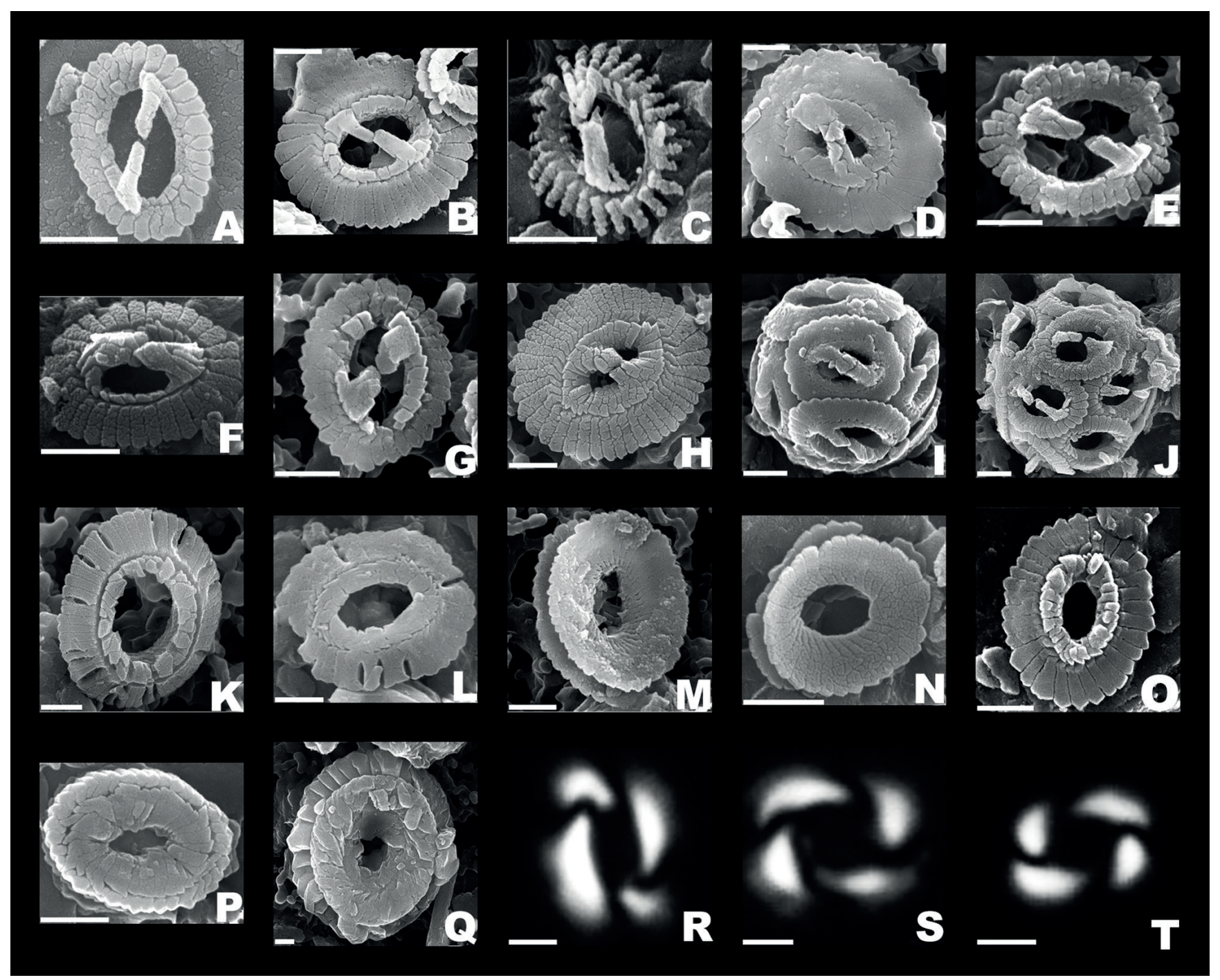

Figure 3. Isochrysadales. Distal shields except 11-12, Cromosphera; 18-19; proximal shields. 3-14; sample 8b from Palma Sola I: 15-17; sample 30b Palma Sola II 18; 20-22. A, Gephyrocapsa aperta Kamptner, 1963 IGMD-109-Mi. S. B, G. margereli Brèhéret, 1978 IGMD-110-Mi. C, G. protohuxleyi McIntyre, 1970 IGMD-111-Mi. D, Gephyrocapsa small type 1 IGMD-112-Mi. E, Gephyrocapsa small Type 2 IGMD-113-Mi. F, Gephyrocapsa small type 3 IGMD114-Mi. G, Gephyrocapsa small type 4 IGMD-115-Mi. H, Gephyrocapsa small type 5 IGMD-116-Mi. I, Gephyrocapsa small type 6 IGMD-117-Mi. J, Gephyrocapsa small type 7 IGMD-118-Mi. K, Pseudoemiliania lacunosa (Kamptner, 1963) Gartner, 1969 IGMD-132-Mi. L, P. ovata (Bukry, 1973) Young, 1998, IGMD-133-Mi. M, Reticulofenestra haqii Backman, 1978 IGMD-134a-Mi. N, R. minuta Roth, 1970 IGMD-135a-Mi.O, R. minutula (Gartner, 1967) Haq \& Berggren, 1978 IGMD-136a-Mi. P, Reticulofenestra sp. 1 IGMD-138-Mi. Q, Reticulofenestra sp. 2 IGMD-139-Mi. R, R. haqii IGMD-134b-Mi. S, R. minuta IGMD-135b-Mi. T, R. minutula IGMD-136b-Mi. Scale bars $=1 \mu \mathrm{m}$.

species allows to do an age assignment. It is in sample 6, located at $1.82 \mathrm{~m}$ from the base that Reticulofenestra haqii and small Gephyrocapsa co-exist. This co-occurrence is indicative of a minimum age equivalent to the lower Pliocene NN15 Reticulofenestra pseudoumbilica Zone of Martini (1971), where $R$. haqii has its last occurrence (LO) in the top of the zone. The presence of small Gephyrocapsa has been recorded in the Equatorial Pacific in rocks older than 4.5 Ma (Pujos, 1987; Site 572). However, there seems to be consensus among the authors to consider a younger age for the first small Gephyrocapsa bloom, which has been calibrated by magnetostratigraphy in $\approx 3.5-3.6 \mathrm{Ma}$ at site 503B in the Equatorial Pacific and in the 502 in the Caribbean Sea region (Rio, 1982).
The absence of other characteristic species does not allow the exactly biostratigraphic location of the middle and upper part of Palma Sola I, and therefore it is only possible to assign it to a time span between the first occurrence (FO) of small Gephyrocapsa and the LO of Reticulofenestra haqii $(\approx 3.5-3.6 \mathrm{Ma})$ in the Zanclean (lower Pliocene) (Gradstein et al., 2012) (Figure 8). In Palma Sola II, 37 samples contain calcareous nannofossils. Sample 30 is the richest and diverse, whereas samples 13 and 26 do not contain microfossils. Sixty species were identified (Figure 9). The most conspicuous are Calcidiscus leptoporus, C. macintyrei, Coccolithus pelagicus, Helicosphaera carteri, H. kamptneri, H. sellii, small Gephyrocapsa, Pontosphaera discopora, P. 


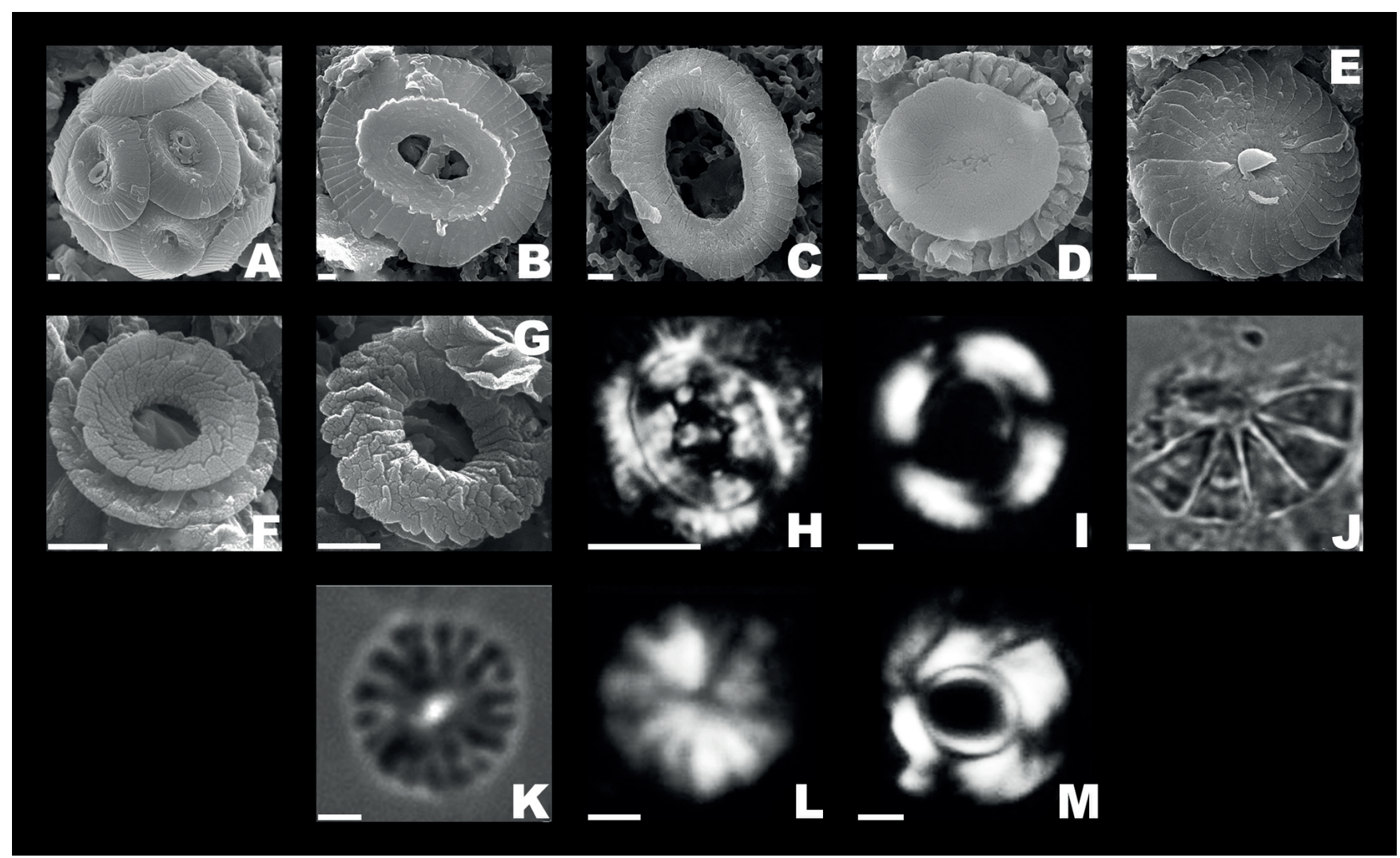

Figure 4. Coccolithales. Distal shields except A, Cocosphere, and D, F, M proximal shields. Sample 30b Palma Sola II: A, D-G, N, sample 6b Palma Sola I: B, H, sample 8b Palma Sola II: I, L, sample 8b Palma Sola I: C, sample 29b Palma Sola II: G, sample 10b Palma Sola II: J, sample 5b Palma Sola II: K. A, Coccolithus pelagicus (Wallich, 1877) Schiller, 1930 IGMD-101-Mi. B, C. pliopelagicus Wise, 1973 IGMD-102a-Mi. C, C. streckeri Takayama \& Sato, 1987 IGMD-103-Mi. D, Calcidiscus leptoporus (Murray \& Blackman, 1898) Loeblich \& Tappan, 1978 IGMD-96-Mi. E, C. macintyrei (Bukry \& Bramlette, 1969) Loeblich \& Tappan, 1978 IGMD-97-Mi. F, Umbilicosphaera foliosa (Kamptner, 1963) Geisen In: Sáez et al., 2003 IGMD-159a-Mi. G, U. sibogae (Weber-van Bosse, 1901) Gaarder, 1970 IGMD-160-Mi. H, C. pliopelagicus Wise, 1973IGMD-102b-Mi. I, Coronocyclus nitescens (Kamptner, 1963) Bramlette and Wilcoxon, 1967 IGMD-104-Mi. J, Hayaster perplexus (Bramlette and Riedel, 1954) Bukry, 1973b IGMD-119-Mi. K, Hayella sp. IGMD-120-Mi. L, Oolitothus sp. IGMD-127-Mi. M, U. foliosa (Kamptneri, 1963) Geisen in Sáez et al. 2003IGMD-159b-Mi. Scale bars $=1 \mu \mathrm{m}$.

japonica, Pseudoemiliania lacunosa, Reticulofenestra haqii, R. minuta, R. minutula, Syracosphaera histrica, S. pulchra, Umbilicosphaera foliosa, and U. sibogae. The calcareous nannofossils are rare to common, moderate well preserved. In addition, some reworked Miocene species were identified, as Discoaster formosus, Helicosphaera ampliaperta, and Helicosphaera burkei. In Palma Sola II the calcareous nannofossils have a homogeneous distribution throughout the sedimentary column. Nevertheless, there are intervals were the record of several species is abruptly interrupted, making it difficult to know if the absence of one species is due to ecological or stratigraphic reasons.

Following the distribution pattern of the index species through the column, it is not possible to give with certainty an age for the Palma Sola II base; nevertheless, the presence of Ceratolithus rugosus that has its FO in the NN13 of the Ceratolithus rugosus Zone (Martini, 1971) allows an age assignment not older than the Pliocene. Pseudoemiliania lacunosa and $P$. ovata co-occurs intermittently from sample five to ten ( 3.27 to $7.55 \mathrm{~m}$ from the base); both are indicative of an age not older than the R. pseudoumbilica (NN15) Zone (Martini, 1971), where P. lacunosa occurs for the first time $(\approx 3.92-3.70 \mathrm{Ma}$, Zanclean stage; Young, 1998).

At Unit III (samples 11, 12, 14; 8.54 to $11 \mathrm{~m}$ from the base), there are no index species recorded. Because no unconformity was observed in the field, it is assumed a continuous sedimentation and therefore an equal or younger age is assigned to this part of the column. Units IV, V, VI and VII (samples $15-25 ; 27-37 ; 12.9$ to $32.63 \mathrm{~m}$ ), in particular from sample 17 (located $14.36 \mathrm{~m}$ from the base) to the top, contain a highly diverse association and the species become more diverse and well preserved. At sample 18 (at 15.45 $\mathrm{m}$ from the base) small Gephyrocapsa, Reticulofenestra minuta, $R$. haqii and $R$. minutula co-dominate and co-exist with an almost homogenous distribution, except for some brief absences, until sample 37 (Unit VII, $32.6 \mathrm{~m}$ ). $R$. minutula have its $\mathrm{FO}(\approx 3.92-3.70 \mathrm{Ma})$ in the Zanclean stage, in the base of the NN15 R. pseudoumbilica Zone (Martini, 1971), whereas $R$. haqii has its LO in the top of this same zone (Bown, 1998). The co-occurrence of these species in 


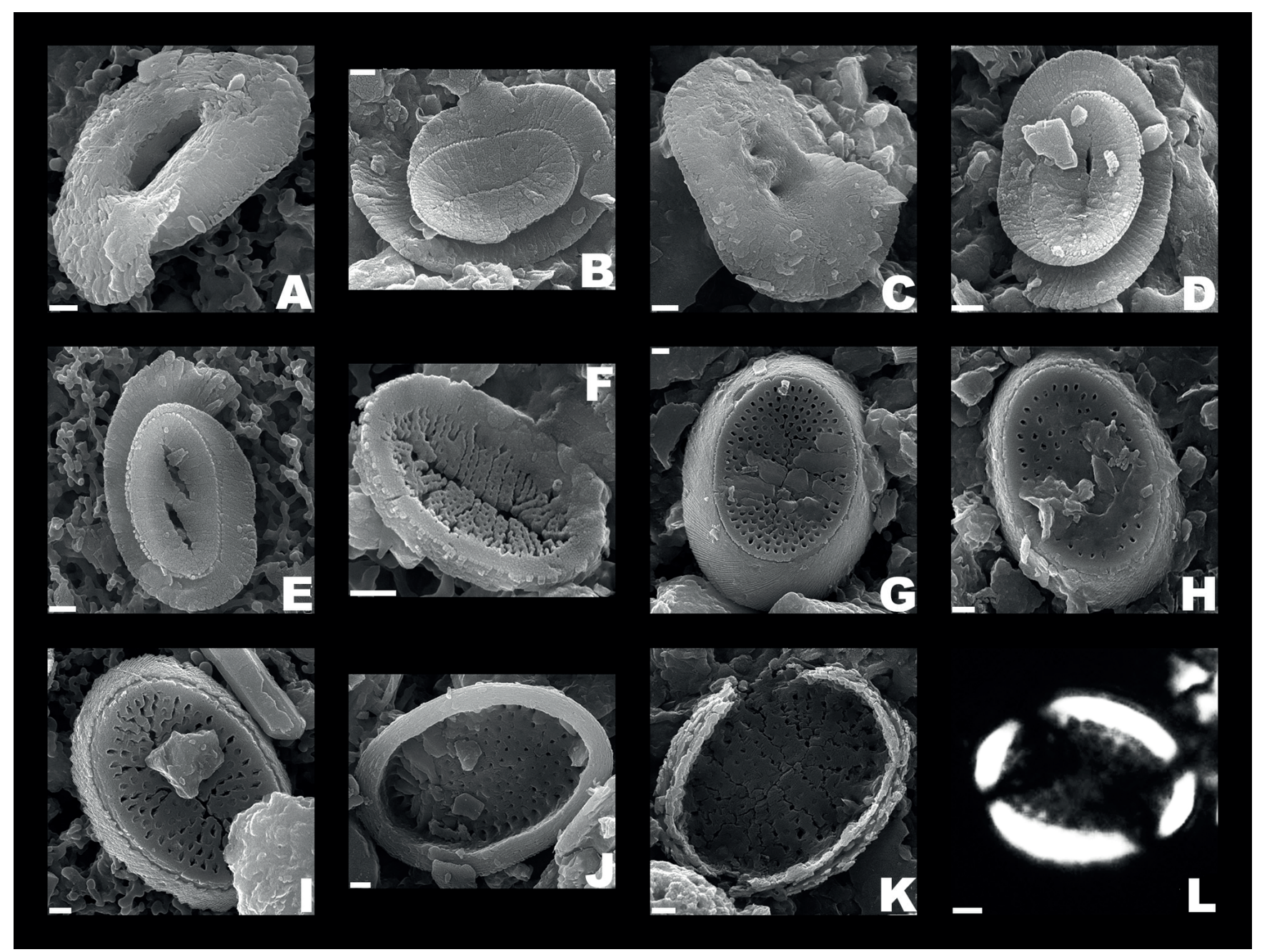

Figure 5. Zygodiscales. Distal shields A, C, F, H, J-L, proximal shields B, D, E, G, F. Sample 8b Palma Sola I: A, B, F-K, sample 30b Palma Sola II: C-E, sample 5b Palma Sola II: L. A, Helicosphaera aff. ampliaperta Bramlette and Wilcoxon, 1967 IGMD-121-Mi. B, H. burkei (Black, 1971) Theodoridis, 1984 IGMD-122-Mi. C, H. carteri (Wallich, 1877) Kamptner, 1954 IGMD-123-Mi. D, H. kamptneri (Hay \& Mohler in Hay et al., 1967) Locker, 1973 IGMD-124Mi. E, H. sellii (Bukry \& Bramlette, 1969) Jafar \& Martini, 1975 IGMD-125-Mi. F, Pontosphaera aff. japonica (Takayama, 1967) Nishida, 1971 IGMD130-Mi. G, P. discopora Schiller, 1925 IGMD-129-Mi. H, P. multipora (Kamptner, 1948) Roth, 1970 IGMD-131-Mi. I, Pontosphaera sp.1 IGMD-159-Mi. J, Pontosphaera sp. 2 IGMD-160-Mi. K, Pontosphaera sp. 3 IGMD-161-Mi. L, P. callosa (Martini, 1969) Varol, 1982 IGMD-128-Mi. Scale bars = 1 $\mu \mathrm{m}$.

samples 17 to 37 situates this part of the deposit into this zone with an age of $\approx 3.6 \mathrm{Ma}$. At Unit VIII (samples 38 and $39,33.72-36 \mathrm{~m}$ ) the absence of reticulofenestrids suggest a younger time interval, equivalent to the Discoaster surculus NN16 Standard Zone (Martini, 1971). Nevertheless, Discoaster and Sphenolithus, as well as other warm to temperate index species, were not recorded at all, and therefore it is not possible to recognize this biozone. In conclusion, the only age that it is possible to assign with certainty for Unit III is equivalent to the lower Pliocene $R$. pseudoumbilica Zone (Martini, 1971), around 3.6 Ma in the Zanclean (Gradstein et al., 2012) (Figure 9).

The calcareous nannofossils recorded through the sedimentary (Figure 3 to 7 ) columns are dominated by medium sized Coccolithus pelagicus s.l., small to medium Reticulofenestra (R. minuta, R. minutula, and R. haqii), small Gephyrocapsa, Helicosphaera spp. and Reticulofenestrids has been associated to tropical upwellings (Okada \& Honjo, 1973), periods of high fertility (Biekart, 1989; Wade and Bown, 2006), and to a shallow, unstable thermocline (Flores et al., 2005). Abundance of small Gephyrocapsa has been considered as indicative of a poorer stratification of surface waters (Gartner et al., 1977), whereas C. pelagicus has been largely considered as indicative of surface cold waters (Okada \& Mclntyre, 1979; Bukry, 1980; Winterer et al., 1994), but its relation with increased productivity has been discussed (e.g. Cachaõ \& Moita, 1995; Filippelli et al., 2003; Boeckel \& Baumann, 2004; Flores et al., 2005). Taxonomic studies (Geisen et al., 2002) separate two subspecies, C. pelagicus pelagicus and $C$. pelagicus braarudii that are considered as related with the presence of cool and temperate water masses, respectively (Cachão \& Moita, 2000). In the Palma Sola columns C. pelagicus is represented mostly by heterococcoliths with bridge and 

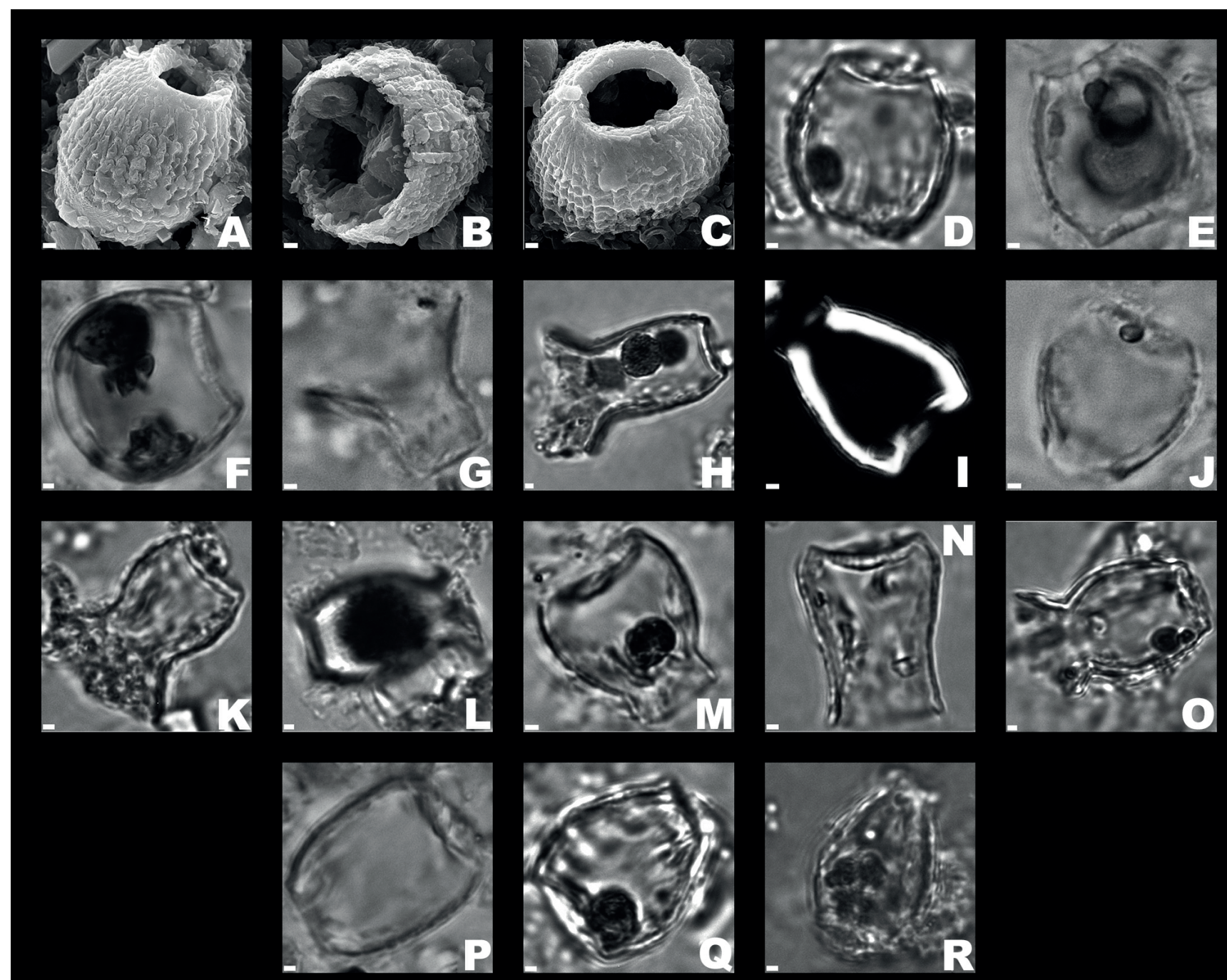

Figure 6. Zygodiscales. Side view, except A-C in distal view, sample 30b Palma Sola II: E-G, J, P-R, sample 8b Palma Sola I: A-C, I, sample 1b Palma Sola I: L-M, sample 9b Palma Sola I: D, sample 6b Palma Sola II: H, sample 10b Palma Sola II: K, sample 5c Palma Sola II: N, sample 24b Palma Sola II: O, sample 6b Palma Sola I: R. A, Scyphosphaera apsteinii Lohmann, 1902 IGMD-140a-Mi. B, S. apsteinii IGMD-140b-Mi. C, Scyphosphaera sp. IGMD-162Mi. D, S. apsteinii IGMD-140c-Mi. E, S. biarritzensis Lezaud, 1968 IGMD-141-Mi. F, S. brevisa Varol, 1984 IGMD-142-Mi. G, S. campanula Deflandre, 1942 IGMD-143-Mi. H, S. darraghi Rade, 1975 IGMD-144-Mi. I. S, gladstonensis Rade, 1975 IGMD-145-Mi. J, S. globulata Bukry \& Percival, 1971 IGMD-146-Mi. K, S. halldali Deflandre in Deflandre \& Fert, 1954 IGMD-147-Mi. L, S. aff. kamptneri Müller, 1974 IGMD-148-Mi. M, S. pacifica Rade, 1975 IGMD-149-Mi. N, S. penna Kamptner, 1955 IGMD-150-Mi. O, S. pulcherrima Deflandre, 1942 IGMD-151-Mi. P, S. recta (Deflandre, 1942) Kamptner, 1955 IGMD-152-Mi. Q, S. recurvata Deflandre, 1942 IGMD-153-Mi. R, S. aff. rottiensis Jafar, 1975IGMD-154-Mi. Scale bars $=1 \mu \mathrm{m}$.

medium sized, that correspond to $C$. pelagicus braarudii and to the intermediate $(10-13 \mu \mathrm{m})$ morphotype illustrated by Parente et al. (2004). Therefore, the abundance of these morphotypes, reticulofenestrids, small Gephyrocapsa, and helicoids, as well as the virtual absence of asteroliths, typical of deep, warm and unproductive environments (Bukry, 1978), strongly suggest that the area was influenced by coastal upwelling. Nevertheless, it must be noted that there may also be an effect due to taphonomic factors, related to a greater resistance to dissolution of these species.

Based on the abundance of Coccolithus pelagicus s.l., small to medium Reticulofenestra spp., small Gephyrocapsa and Helicosphaera spp., it is inferred a temperate $\left(14^{\circ}\right.$ to $17^{\circ} \mathrm{C}$ ), eutrophic, nearshore environment with high terrigenous input and influenced by coastal upwelling. Moreover, absence of warm open sea water, sphenoliths and discoasters (Haq \& Lohmann, 1976, 1977; Haq, 1980; Backman et al., 1986; Wei \& Wise, 1990), together with the low and monotonous diversity exhibited throughout the whole studied columns, strongly suggests a dynamic nearshore setting. Additionally, abundance of Scyphosphaera species seems to confirm the nearshore warm water environment.

\section{DISCUSSION}

Taking in consideration the microfossils reported by Umhoefer et al. (2007) and those reported and illustrated here, and its ranges updated, several considerations they 


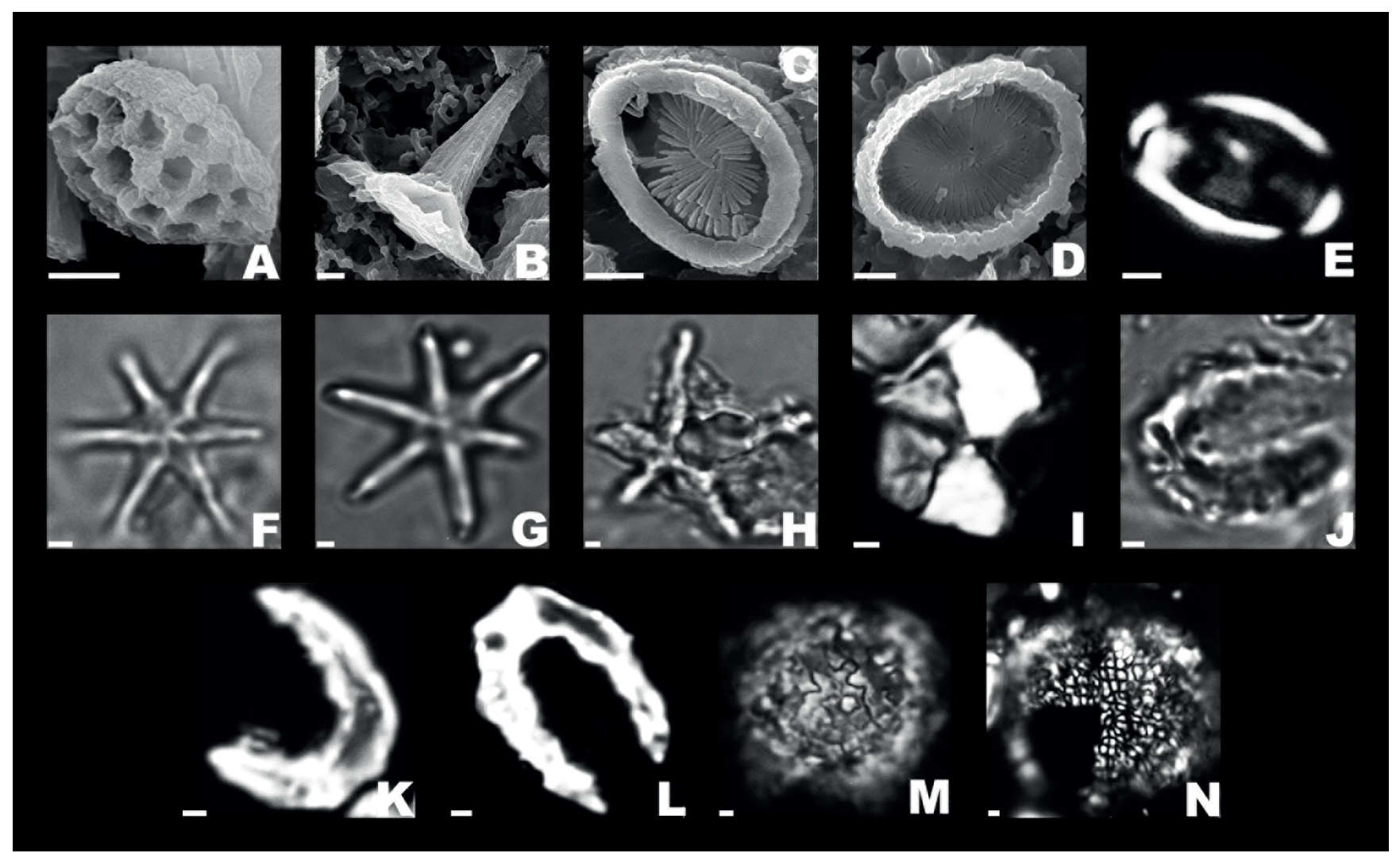

Figure 7. Nannolith Incertae sedis; Noncocco; Calcareous dinoflagellates. Distal view Discoasterales A, C-G, proximal view; M-N, side view; B, proximal view; H, sample 18b Palma Sola II: D-E, G, sample 8b Palma Sola I: B-C, sample 30b Palma Sola II: A, sample 9b Palma Sola II: F, sample 17b Palma Sola II: H, sample 7a Palma Sola II: I, sample 10b Palma Sola II: J, sample 9b Palma Sola II: K, sample 5b Palma Sola I: L, sample 9b Palma Sola I: M, sample 4b Palma Sola I. A, Holodiscolithus macroporus (Deflandre in Deflandre \& Fert, 1954) Roth, 1970IGMD-126-Mi. B, Discosphaera tubifera (Murray \& Blackman, 1898) Ostenfeld, 1900 IGMD-108-Mi. C, Syracosphaera histrica Kamptner, 1941 IGMD-155-Mi. D, S. pulchra Lohmann, 1902 IGMD-156a-Mi. E, S. pulchra IGMD-156b-Mi. F, Discoaster brouweri Tan, 1927 emend. Bramlette \& Riedel, 1954 IGMD-105-Mi. G, D. formosus Martini \& Worsley, 1971 IGMD-106-Mi. H, D. aff. pentaradiatusTan, 1927 IGMD-107-Mi. I, Braarudosphaera bigelowii (Gran and Braarud, 1935) Deflandre, 1947 IGMD-95-Mi. J, Ceratolithus cristatus Kamptner, 1950 IGMD-98-Mi. K, C. rugosus Bukry \& Bramlette, 1968 IGMD-99-Mi. L, Ceratolithus sp. IGMD-100-Mi. M, Cervisiella saxea (Stradner, 1961) Hildebrand-Habel, Willems \& Versteegh, 1999 IGMD-158-Mi. N, Thoracosphaera fossata Jafar, 1975 IGMD-157-Mi. Scale bars = $1 \mu$ m.

must necessarily be underlined. Concerning the calcareous nannofossils, Umhoefer et al. (2007) stated that the presence (in sample 25, section X; Figure 2) of Emiliania ovata and the lack of "two early Pliocene species which are normally common even in restricted assemblages" (sic) is enough evidence to consider the deposit as of Late Pliocene age, into the CN12 Discoaster brouweri Zone (Bukry, 1973a; 1975; Okada \& Bukry, 1980). Nevertheless, E. ovata has its FO at 3.92-4.13 Ma and its LO at 0.44-1.93 Ma (Young, 1998); therefore, its presence does not support by itself an age assignment of late Pliocene for the whole unit.

This late Pliocene age (2.5-2.4 Ma) for an interval that include samples 16 to 31 (section X; Figure 2) is reinforced by Umhoefer et al. (2007) based on the presence of the planktonic foraminifers Globorotalia ungulata Bermúdez, sinistral forms of Pulleniatina primalis Banner \& Blow, the presence of Pulleniatina praecursor Banner \& Blow, and the absence of Pulleniatina obliquiloculata s.s. Banner \& Blow. Nevertheless, G. angulata is a shallow dwelling juvenile of G. tumida (Brown, 2007), which have its FO at $5 \mathrm{Ma}$, whereas the $\mathrm{FO}$ of G. ungulata is unclear and no attempt was made to situate its first occurrence in the geological record. A mid-Zanclean to Recent stratigraphic range for this species has been reported (BouDagher-Fadel, 2013). Likewise, the age interval of 2.5-2.4 Ma interpreted by Umhoefer et al. (2007) based in the presence of sinistral Pulleniatina primalis corresponds to a circular reasoning, since there is no way to verify that this event corresponds to the 2.7 Ma dextral-sinistral shift occurring in the Pacific DSDP Site 157 (Keigwin, 1978), especially when it is not possible to document an older or a continuous record of the genera in the studied area to allow the verification of well chronostratigraphic constrained shifts in the Pulleniatina coiling. On the other hand, P. precursor is considered an Atlantic species characteristic of a short time interval around 3.6 Ma (Bolli \& Saunders, 1985). In the Eastern Tropical Pacific, the closest record of this species is located in Maria Madre island off the coast of México, where an age of $\approx 3.1$ Ma was assigned based on the presence of $P$. obliquiloculata (Parker \& Jones), P. praecursor, and Neogloboquadrina dutertrei (d'Orbigny) while the rocks without $P$. praecursor are considered to have younger age (McCloy et al., 1988). 


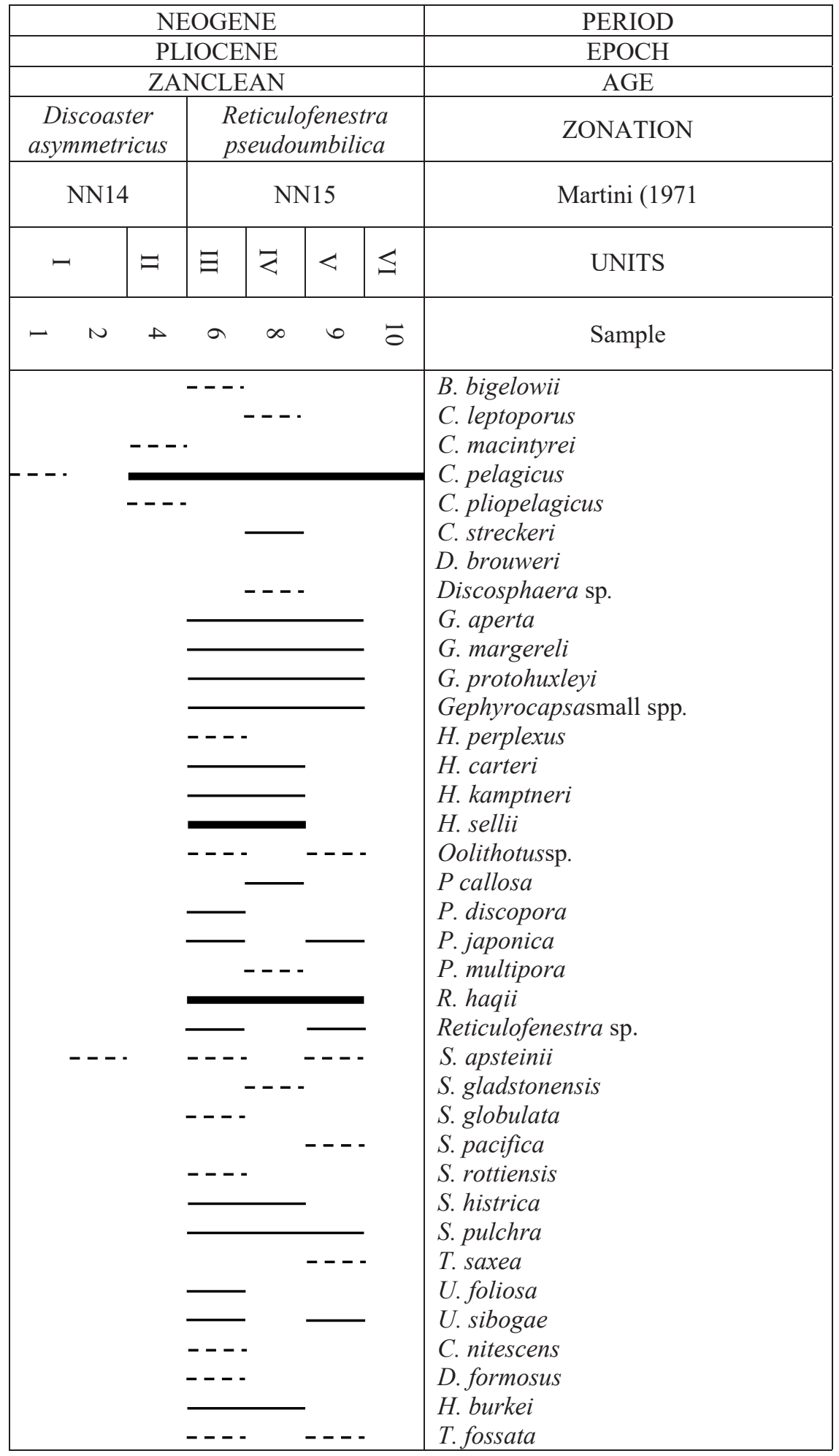

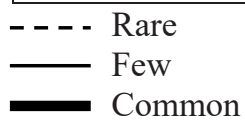

Figure 8. Calcareous nannofossils recorded throughout column Palma Sola I, San José Island, Baja California Sur, Mexico. 


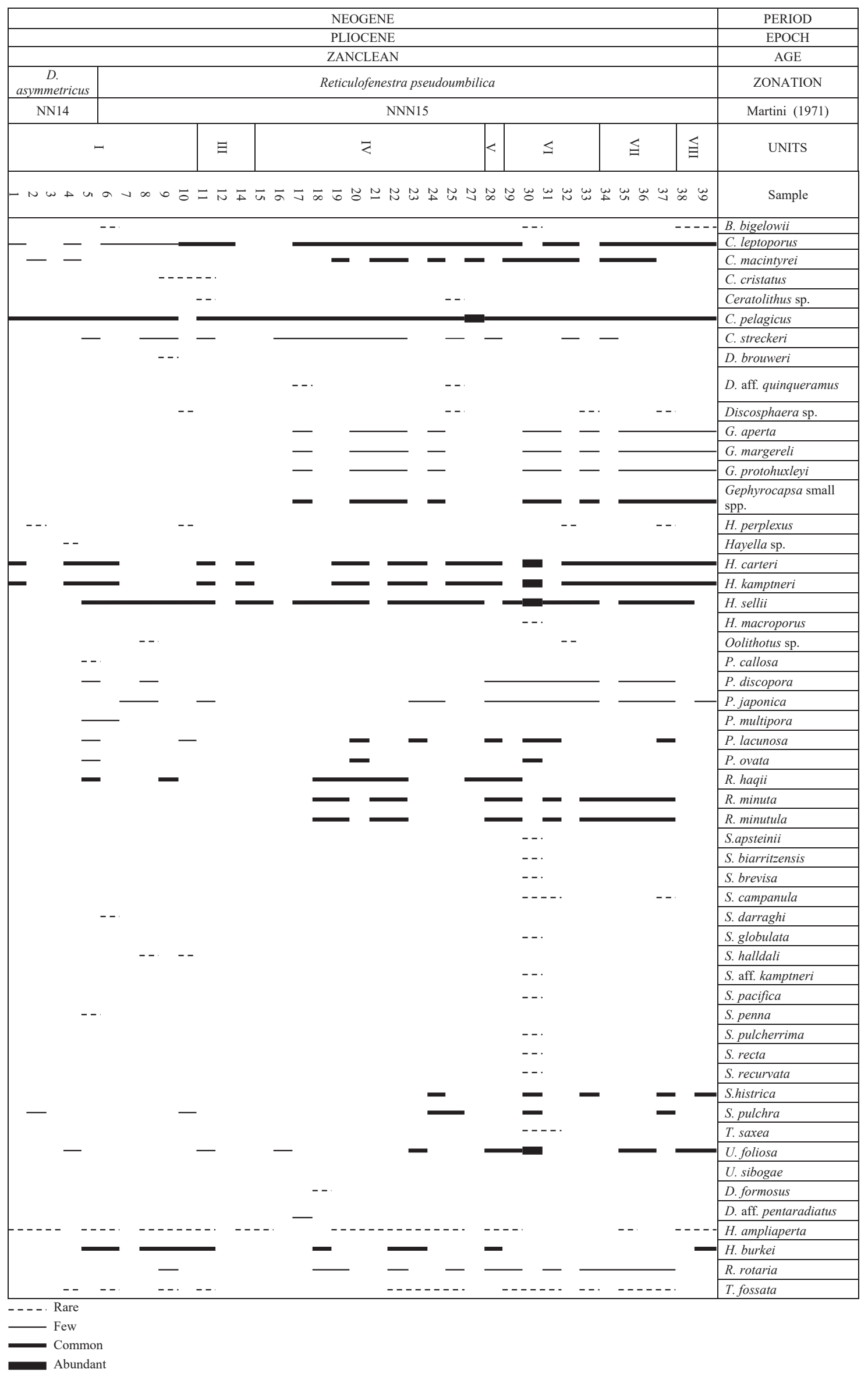

Figure 9. Calcareous nannofossils recorded throughout column Palma Sola II, San José Island, Baja California Sur, Mexico. 
Absence of $P$. obliquiloculata is considered by Umhoefer et al. (2007) as indicative of a younger age because the genus disappears in the Atlantic realm from 3.5-2.5 Ma, but once again the fact is that in the Pacific it has a continuous record.

In the present study, sinistral forms of $P$. obliquiloculata and $P$. primalis were recovered, and are the most conspicuous planktonic foraminifers together with Globigerina bulloides (d'Orbigny) plexus, Neogloboquadrina dutertrei (d'Orbigny), Globigerinoides ruber (d'Orbigny), Globigerinoides quadrilobatus (d'Orbigny), Orbulina. universa d'Orbigny, P. primalis, P. obliquiloculata and Globorotalia tumida, Globorotalia menardii, and variants. Other species are rare, poorly preserved, and sparsely distributed. It is noticed that no Globorotalia ungulata Bermúdez, Groborotalia exilis Blow, Globorotalia limbata Fornasini or Pulleniatina alticuspis Carreño, were recorded.

No attempt was made here to study siliceous microfossils, but according to Umhoefer et al. (2007) the assemblage recovered by them from one sample of diatomaceous siltstone located $10 \mathrm{~m}$ stratigraphically below their sample 15 (sic), corroborates an age of 2.4-2.0 Ma. An updated revision of the data (FO and LO) of the siliceous species used to assign the age of the La Gata Mudstone by Umhoefer et al. (2007), following the criteria of the diatom (Burckle, 1972; Barron, 1985) and silicoglagellate biozonations (Bukry, 1972, 1981) indicate that an older age interpretation is possible (Figure 8). Umhoefer et al. (2007) reports an age of 2.4-2.0 Ma due to the presence of Rhizosolenia praebergonii Mukhina, Azpeitia nodulifera var. cyclopus (Jousé) Fryxell \& Sims, Asteromphalus elegans Greville, and the absence of Fragilariopsis doliolus (Wallich) Medlin \& Sims, Nitzschia jouseae Burckle and Thalassiosira convexa Mukhina, and the silicoflagellate Dictyocha staepedia Haeckel. If as stated by Umhoefer et al. (2007) the absence of $N$. jouseae, A. elegans, $T$. convexa var. convexa and $F$. doliolus in the diatomaceous siltstones of La Gata mudstone is due to stratigraphic reasons, then, according with the stratigraphic ranges of these species (Figure 8) the age of these rocks must be situated after $2.1 \mathrm{Ma}$, when $T$. convexa have its LO.

However, if the age is based on the stratigraphic ranges of the species as Rhizosolenia praebergonii, Asteromphalus elegans, and Azpeitia nodulifera var cyclopus, the estimated age for this sample must be not older than $\approx 3.0$ (datum of the FO of $R$. praebergonii). The presence of Dictyocha stapedia, used by Umhoefer et al. (2007) to assign a final age of 2.5-2.4 Ma for the whole marine rocks, occurs for the first time into the $N$. jouseae Zone (Burckle, 1972; Barron, 1985) around 3.0 Ma.

Thus, taking in account only the taxa recorded by Umhoefer et al. (2007) instead of the absences, the consensus age for the La Gata mudstone is around 3.7-3.0 Ma, that following Gradstein (2012) situates the sedimentary column here studied in the boundary between the lower Pliocene and the upper Pliocene (Zanclean-Piazencian). The $\mathrm{Ar}^{40} / \mathrm{Ar}^{39}(3.1 \pm 0.5-3.6 \mathrm{Ma})$ age provided by Umhoefer $\mathrm{et} \mathrm{al}$. (2007) from the tuffaceous sandstone in the western portion of Punta Colorada sub-basin is consistent with the results here presented but also with the updated data published by Umhoefer et al. (2007).

The presence of an intensive upwelling associated to the La Gata mudstone deposit indicated by the calcareous nannofossils assemblages need to be explained within a warm period. According with Dekens et al. (2007), around 4.6-3.1 Ma the sea surface temperature of the Eastern Equatorial Pacific at the California margin was warmer than today by $3-9^{\circ} \mathrm{C}$, and cold upwelling regions did not exist in the early Pliocene in the same way that they occur today. In contrast, Bakun (1990) considered that under global warming upwelling regions might, become even more pronounced. Consequently, the warmer conditions described by Dekens et al. (2007) can be an example of upwelling for the early Pliocene in the newly formed Gulf of California.

In conclusion, the calcareous nannofossils here recorded throughout the upper part of the La Gata mudstone, gives an older age that the previously proposed by Umhoefer et al. (2007) for the upper Sequence 3 (within the La Gata mudstone), whereas the updated revision of the biostratigraphic data of diatoms, silicoflagellates, planktonic foraminifera, and calcareous nannofossils used by those authors (Table 1) allow us to estimate an age of 3.7-3.0 Ma for the La Gata mudstone, at least for its lower and middle part, which fits well with the age here proposed of $\approx 3.6 \mathrm{Ma}$.

Table 1. Diatoms and Silicoflagellates mentionned by Umfohefer et al. (2007) from a diatomaceous siltstone located aproximately at $30 \mathrm{~m}$ from the base of the la Gata mudstone in their Column X at the Palma Sola Basin. Biozones by 1) Burckle (1972) \& Barron (1985) for diatoms, 2) Bukry (1972, 1981) for silicoflagellates. Updated Datum by 3) Clemens et al. (2016a,b); 3) Sims et al. (1989) and Shiono \& Koizumi (2002); 4) Barron (1992); 5) Guiry in Guiry \& Guiry (2018).

\begin{tabular}{|c|c|c|}
\hline Species & FO & LO \\
\hline Rhizosolenia praebergonii & $\begin{array}{c}\text { base of } R \text {. praebergonii Zone }{ }^{1,4} \\
\approx 3.0 \mathrm{Ma}\end{array}$ & $\begin{array}{l}\text { top of Nitzschia reinholdi Subzone A, at } 1.8 \\
\qquad \mathrm{Ma}^{1,4}\end{array}$ \\
\hline Fragilariopsis doliolus & top of Nitzschia reinholdi Subzone ${ }^{1}$ at $1.8 \mathrm{Ma}^{1,4}$ & Recent \\
\hline Nitzschia jouseae & $4.5 \mathrm{Ma}^{4}$ & $2.6 \mathrm{Ma}^{4}$ \\
\hline Thalassiosira convexa var. convexa & $3.6 \mathrm{Ma}^{4}$ & $2.1 \mathrm{Ma}^{4}$ \\
\hline Asteromphalus elegans & $3.9 \mathrm{Ma}^{2,4}$ & Recent $^{5}$ \\
\hline Azpeitia nodulifera var. cyclopus & 7.9-7.0 $\mathrm{Ma}^{3}$ & Recent $^{4}$ \\
\hline Dictyocha stapedia & 3.0 Ma into the $N$. jouseae Zone ${ }^{2}$ & \\
\hline
\end{tabular}




\section{ACKNOWLEDGMENTS}

Authors are indebted with two anonymous referees that largely contributed to improve the paper with their careful and constructive revision. We would like to thank Y. Hornelas, L.E Gómez-Lizárraga and D.V. Hernández-Becerril, (ICMyL, UNAM) for her technical support with the SEM and laboratory facilities, respectively. Financial support was provided by the Programa de Apoyo a Proyectos de Investigación e Innovación Tecnológica (PAPIIT), UNAM projects IN102211 and IN102314 "Sincronizando relojes durante el Neógeno: implicación en la edad de las primeras incursiones marinas del Protogolfo de California" and "¿Existió el protogolfo de California en el Mioceno medio?”.

\section{REFERENCES}

Applegate, S.P. \& Carranza-Castañeda, O. 1993. El primer reporte de un mamífero fósil de las islas del Golfo de California. In: INTERNATIONAL MEETING ON THE GEOLOGY OF THE BAJA CALIFORNIA PENINSULA, 2, 1993. Proceedings and Abstracts, Universidad Autónoma de Baja California \& Sociedad Geológica Peninsular, p. 4.

Backman, J. 1978. Late Miocene-Early Pliocene nannofossil biochronology and biogeography in the Vera Basin, SE Spain. Stockholm Contributions in Geology, 32:93-114.

Backman, J.; Schneider, D.A.; Rio, D. \& Okada, H. 1990. Neogene low latitude magnetostratigraphy from Site 710 and revised age estimates of Miocene nannofossil datum events. Proceedings of the Ocean Deep Project, 115:271-276

Barron, J.A. 1985. Miocene to Holocene planktic diatoms. In: H.M. Bolli; J.B. Saunders \& K. Perch-Nielsen (eds.) Plankton Stratigraphy, Cambridge University Press, p. 763-809.

Barron, J.A. 1992. Neogene Diatom Datum levels in the Equatorial and North Pacific. In: K. Ishizaki \& T. Saito (eds.) Centenary of Japanese Micropaleontology, Terra Scientific Company, p. 413-125.

Bakun, A. 1990. Global climate changes and intensification of coastal upwelling. Science, 247:198-201. doi:10.1126/ science.247.4939.198

Biekart, J.W. 1989. The distribution of calcareous nannofossils in late Quaternary sediments collected by the Snellius II expedition in some southeast Indonesian basins. Proceedings of the Koninklijke Nederlandse Akademie van Wetenschappen. Series B, Physical sciences, 92:77-141.

Black, M. 1971. The systematics of coccoliths in relation to the paleontological record. In: B.M. Funnell \& W.R. Riedel (eds.) The Micropaleontology of the Oceans, Cambridge University Press, p. 611-624.

Blow, W.H. 1969. Late middle Eocene to Recent planktonic foraminiferal biostratigraphy. In: INTERNATIONAL CONFERENCE ON PLANKTONIC MICROFOSSILS, 1, 1967. Proceedings, Geneva, Leiden E. J. Brills, p. 199-422.

Boeckel, B. \& Baumann, K.-H. 2004. Distribution of coccoliths in surface sediments of the south-eastern South Atlantic Ocean: ecology, preservation and carbonate contribution. Marine Micropaleontology, 51:301-320. doi:10.1016/j. marmicro.2004.01.001

Bolli, H.M. \& Saunders, J.B. 1985. Oligocene to Holocene low latitude planktonic foraminifera. In: H.M. Bolli; J.B. Saunders \& K. Perch-Nielsen (eds.) Plankton Stratigraphy, Cambridge University Press, p 155-262.
Bollmann, J.; Cortés, M.Y.; Haidar, A.T.; Brabec, B.; Close, A.; Hofmann, R.; Palma, S.; Tupas, L. \& Thierstein, H.R. 2002. Techniques for quantitative analyses of calcareous marine phytoplankton. Marine Micropaleontology, 44:163-185. doi:10.1016/S0377-8398(01)00040-8

BouDagher-Fadel, M.K. 2013. Biostratigraphic and geological significance of planktonic Foraminifera. $2^{\text {nd }}$ ed. London, UCL, 287 p.

Bown, P.R. 1998. Calcareous nannofossil biostratigraphy. London, Chapman \& Kluwer Academic Publishers, 314 p.

Bramlette, N. \& Riedel, W.R. 1954. Stratigraphic value of discoasters and some other microfossils related to Recent coccolithophores. Journal of Paleontology, 28:385-403.

Bramlette, N. \& Sullivan, F. 1961. Coccolitophorids and related nannofossils of the early Tertiary in California. Micropaleontology, 7:129-188.

Bramlette, N. \& Wilcoxon, A. 1967. Middle Tertiary calcareous nannofossils of the Cipero Section Trinidad, W.I. Tulane Studies in Geology, 5:93-131.

Bréhéret, J.G. 1978. Formes nouvelles quaternaries et actualles de la famille des Gephyrocapsaceae (Cocolithophorides). Comptes Rendus Hebdomadaires des Séances de l'Académie des Sciences, 287:447-449.

Brown, K.R. 2007. Biogeographic and morphological variation in Late Pleistocene and Holocene Globorotalia Foraminifera. University of Basel, Ph.D. Thesis, 170 p.

Bukry, D. 1971. Cenozoic calcareous nannofossils from the Pacific Ocean. San Diego Society Natural History Transactions, 16:303-327.

Bukry, D. 1972. Further comments coccoliths stratigraphy, Leg 12, Deep Sea Drilling Project. In: A.S. Laughton et al. (eds.) Deep Sea Drilling Project, Washington, DSDP, p. 1071-1083 (Initial Reports 12). doi:10.2973/dsdp.proc.12.116.1972

Bukry, D. 1973a. Low-latitude coccolith biostratigraphic zonation. In: N.T. Edgar; A.G. Kaneps \& J.R. Herring (eds.) Deep Sea Drilling Project, Washington, DSDP, p. 685-703 (Initial Reports 15). doi:10.2973/dsdp.proc.15.116.1973

Bukry, D. 1973b. Phytoplankton stratigraphy, Deep Sea Drilling Project Leg 20, Western Pacific Ocean. In: C. Bruce et al. (eds.) Deep Sea Drilling Project, DSDP, p. 307-317 (Initial Reports 20). doi:10.2973/dsdp.proc.20.114.1973

Bukry, D. 1975. Coccolith and silicoflagellate stratigraphy, northwestern Pacific Ocean Deep Sea Drilling Project Leg 32. In: J.V. Gardner (ed.) Deep Sea Drilling Project, Washington, DSDP, p. 677-701 (Initial Reports 32). doi:10.2973/dsdp. proc. 32.124 .1975

Bukry, D. 1978. Biostratigraphy of Cenozoic marine sediments by calcareous nannofossils. Micropaleontology, 24:44-60.

Bukry, D. 1981. Pacific Coast coccolith stratigraphy between Point Conception and Cabo Corriente. In: R.S. Yeats; B.U. Haq \&. K.A. Pisciotto (eds.) Deep Sea Drilling Project, Washington, DSDP, p. 445-471 (Initial Reports 63). doi:10.2973/dsdp. proc. 63.111 .1981

Bukry, D. \& Bramlette, M.N. 1969. Some new and stratigraphically useful calcareous nannofossils of the Cenozoic. Tulane Studies in Geology, 7:131-142.

Bukry, D. \& Percival, S.F. 1971. New Tertiary calcareous nannofossils. Tulane Studies in Geology and Paleontology, 8:123-146.

Burckle, L.H. 1972. Late Cenozoic planktonic diatom zones from the eastern equatorial Pacific. Nova Hedwigia.Beihefte, 39:217.

Cachão, M. \& Moita, M.T. 1995. Coccolithus pelagicus, a sort of productivity proxy? Journal of Nannofossils Research, 17:50-51.

Cachão, M. \& Moita, M.T. 2000. Coccolithus pelagicus, a productivity proxy related to moderate fronts off Western Iberia. Marine Micropaleontology, 39:131-155. doi:10.1016/S03778398(00)00018-9 
Carreño, A.L. 1992a. Neogene microfossils from the Santiago Diatomite, Baja California Sur, Mexico. In: M. Alcayde-Orraca \& A. Gómez-Caballero (eds.) Calcareous Neogene microfossils of Baja California Sur, Universidad Nacional Autónoma de México, Instituto de Geología, Paleontología Mexicana, p. 1-37.

Carreño, A.L. 1992b. Early Neogene Foraminifera and associated microfossils of the Cerro Tierra Blanca Member (El Cien Formation), Baja California Sur, Mexico. In: M. AlcaydeOrraca, M. \& A. Gómez-Caballero (eds.) Calcareous Neogene microfossils of Baja California Sur, Universidad Nacional Autónoma de México, Instituto de Geología, Paleontología Mexicana, p. 39-93.

Clemens, S.C. et al. 2016a. Expedition 353 methods. In: INTERNATIONAL OCEAN DISCOVERY PROGRAM, 353, 2016. Proceedings, Texas, IODP. doi:10.14379/iodp. proc. 353.102 .2016

Clemens, S.C. et al. 2016b. Site U1443. In: INTERNATIONAL OCEAN DISCOVERY PROGRAM, 353, 2016. Proceedings, Texas, IODP. doi:10.14379/iodp.proc.353.103.2016

Coleman, T.A. 1979. Nannofossils biostratigraphy of the Tepetate formation, Baja California Sur. University of Southern California, Master in Science, 62 p.

Colleta, B. \& Angelier, J. 1981. Faulting evolution of the Santa Rosalía Basin, Baja California Sur, Mexico. In: L. Ortlieb \& J. Roldan (eds.) Geology of Northwestern Mexico and Southern Arizona. Field guides and papers, Universidad Nacional Autónoma de México, Instituto de Geología, p. 265-274.

Deflandre, G. 1942. Coccolithophoridés fossiles d'Oranie. Genres Schyphosphaera Lohmann et Thorosphaera Ostenfeld. Société d'Histoire Naturrelle de Toulouse, Bulletin, 77:125-137.

Deflandre, G. 1947. Braarudosphaera nov. gen., type d'une famille nouvelle de Coccolithophorides actuels a elements composites. Comptes Rendus Hebdomadaires des Séances de l'Académie des Sciences, 225:439-441.

Deflandre, G. \& Fert, C. 1954. Observations sur les coccolithophoridés actuels et fossiles en microscopie ordinaire et électronique. Annales de Paléontologie, 40:115-176.

Dekens, P.S.; Ravelo, A.C. \& McCarthy, M.D. 2007. Warm upwelling regions in the Pliocene warm period. Paleoceanography, 22:PA3211. doi:10.1029/2006PA001394

Dorsey, R.J.; Umhoefer, P.J.; Ingle, J.C. \& Mayer, L. 2001. Late Miocene to Pliocene stratigraphic evolution of northeast Carmen island, Gulf of California: implications for oblique-rifting tectonic. Sedimentary Geology, 144:97-123. doi:10.1016/ S0037-0738(01)00137-3

Fedorov, A.V.; Dekens, P.S.; McCarthy, M.; Ravelo, A.C.; deMenocal, P.B.; Barreiro, M.; Pacanowski, R.C. \& Philander, S.G. 2006. The Pliocene paradox (mechanisms for a permanent El Niño). Science, 312:1485-1489. doi:10.1126/science. 1122666

Filippelli, G.M.; Sierro, F.J.; Flores, J.A.; Vazquez, A.; Utrilla, R.; Perez-Folgado, P. \& Latimer, J.C. 2003. A sediment-nutrientoxygen feedback responsible for productivity variations in Late Miocene sapropel sequences of the western Mediterranean. Palaeogeography, Palaeoclimatology, Palaeoecology, 190:335348. doi:10.1016/S0031-0182(02)00613-2

Flores, J.A.; Sierro, F.J.; Filipelli, G.M.; Bárcena, M.A.; PérezFolgado, M.; Vázquez, A. \& Utrilla, R. 2005. Surface water dynamics and phytoplankton communities during deposition of cyclic late Messinian sapropel sequences in the western Mediterranean. Marine Micropaleontology, 56:50-79. doi:10.1016/j.marmicro.2005.04.002

García-Cordero, E. \& Carreño, A.L. 2009. Upper lower Eocene calcareous nannofossils from the Las Pocitas core (Tepetate formation), Baja California Sur, Mexico. Revista Mexicana de Ciencias Geológicas, 26:37-47.

Gaarder, K.R. 1970. Three new taxa of Coccolithineae. Nytt Magasin for Botanikk, 17:113-126.

Gartner, S. 1967. Calcareous nannofossils from Neogene of Trinidad, Jamaica, and Gulf of Mexico. Lawrence, University of Kansas, p. 1-7 (Paleontological Contributions 29).

Gartner, S. 1969. Correlation of Neogene planktonic foraminifera and calcareous nannofossil zones. Transactions of the Gulf Coast Association of Geological Societies, 19:585-599.

Gartner, S. 1971. Calcareous nannofossils from the Joids Blake Pateu cores and revision of Paleogene nannofossils zonation. Tulane Studies in Geology and Paleontology, 8:101-121.

Gartner, S. 1977. Calcareous nanofossil biostratigraphy and revised zonation of the Pleistocene. Marine Micropaleontology, 2:1-25. doi:10.1016/0377-8398(77)90002-0

Gartner, S. 1977. Paleoceanography of the mid-Pleistocene. Marine Micropaleontology, 13:23-46. doi:10.1016/03778398(88)90011-4

Geisen, M.; Billard, C.; Broerse, A.T.C.; Cros, L.; Probert, I. \& Young, J.R. 2002. Life-cycle associations involving pairs of holococcolithophorid species: intraspecific variation or cryptic speciation? European Journal of Phycology, 37:531-555 doi:10.1017/S0967026202003852

Gómez-Sánchez, D.P. 2013. Estratigrafía de la Formación Trinidad en la localidad El Torote, Baja California Sur, México. Universidad Autónoma de Baja California Sur, Tesis de Licenciatura, $61 \mathrm{p}$

Gonzáles-Bourillon, L.; Cantú, A.; Eccardi, F.; Lira, E.; Ramírez, J.; Velarde, E. \& Zavala, A. 1988. Islas del Golfo de California. SEGOB/UNAM, 292 p.

Gradstein, F.; Ogg, J.; Schmitz, M. \& Ogg, G. 2012. The Geologic Time Scale 2012. Boston, Elsevier, 1176 p.

Gran, H.H. \& Braarud, T. 1935. A quantitative study of the phytoplankton in the Bay of Fundy and the Gulf of Maine (including observations on hydrography, chemistry and turbidity). Journal of the Biological Board of Canada, 1:279467.

Guiry, M.D. \& Guiry, G.M. 2018. AlgaeBase. Galway, National University of Ireland. Available at http://www.algaebase.org; accessed on 11/12/2018.

Hanna, G.D. \& Hertlein, L.G. 1927. Expedition of the California Academy of Sciences to the Gulf of California in 1921. Geology and Paleontology. San Francisco, California Academy of Sciences, p. 137-157 (Proceedings 16).

Haq, B.U. 1980. Biogeographic history of Miocene calcareous nannofossils and paleoceanography of the Atlantic Ocean. Micropaleontology, 26:414-443.

Haq, B.U. \& Berggren, W.A. 1978. Late Neogene calcareous plankton biochronology of the Rio Grande Rise (South Atlantic Ocean). Journal of Paleontology, 52:1167-1194.

Haq, B.U. \& Lohmann, G.P. 1976. Early Cenozoic calcareous nannofossils biogreography of the Atlantic Ocean. Marine Micropaleontology, 1:119-194. doi:10.1016/03778398(76)90008-6

Haq, B.U.; Lohmann, G.P. \& Wise, S.W. 1977. Calcareous nannofossils biogeography and its paleoclimatic implications: Cenozoic of the Falkland Plateau (DSDP Leg 36) and Miocene of the Atlantic Ocean. In: P.F. Barker et al. (eds.) Deep Sea Drilling Project, Washington, DSDP, p. 745-760 (Initial Reports 36). doi:10.2973/dsdp.proc.36.114.1977

Hay, W.W.; Mohler, H.P.; Roth, P.H.; Schmidt, R.R. \& Boudreaux, J.E. 1967. Calcareous nannofossils zonation of the Cenozoic of 
the Gulf Coast and Caribbean-Antillean area, and transoceanic correlation. Transactions of the Gulf Coast Association of Geological Societies, 17:428-480.

Jafar, S.A. 1975. Calcareous nannofossils from the Miocene of Rotti, Indonesia. Koninklijke Nederlandse Akademie van Wetenschappen; Afdeling Natuurunde Verhandelingen, 28:1-99.

Jafar, S.A. \& Martini, E. 1975. On the validity of the calcareous nannofossils genus Helicosphaera. Senckenbergiana Lethaea, 56:381-397.

Jordan, R.W. \& Chamberlain, A.H.L. 1997. Biodiversity among Haptophyte algae. Biodiversity and Conservation, 6:131-152. doi:10.1023/A:1018383817777

Kamptner, E. 1941. Die Coccolithineen der Südwestküste von Istrien. Annalen des Naturhistorischen Museums in Wien, 51:54-149.

Kamptner, E. 1948. Coccolithen aus dem Torton des Inneralpinen Wiener Beckens. Anzeiger. Österreichische Akademie der Wissenschaften. Mathematische-Naturwissenschafliche Klasse. Wien, 157:1-16.

Kamptner, E. 1950. Über den submikroskopischen Aufbau der Coccolithen. Anzeiger. Österreichische Akademie der Wissenschaften. Mathematische-Naturwissenschafliche Klasse. Wien, 87:152-158.

Kamptner, E. 1954. Untersuchungen über den Feinbau der Coccolithen. Anzeiger. Österreichische Akademie der Wissenschaften. Mathematische-Naturwissenschafliche Klasse. Wien, 87:152-158.

Kamptner, E. 1955. Fossile Coccolithineen-Skelettreste aus Insulinde. Eine mikropaläontologische Untersuchung. KoninklijkeNederlandse. Akademie van Wetenschappen; Afdeling Natuurkunde Verhandelingen, 50:1-105.

Kamptner, E. 1963. Coccolithineen-Skelettreste aus Tiefseeablagerungen des Pazifischen Ozeans. Annalen des Naturhistorischen Museums in Wien, 66:139-204.

Keigwin, L.D. 1978. Pliocene closing of the Isthmus of Panama, based on biostratigraphic evidence from nearby Pacific Ocean and Caribbean Sea cores. Geology, 6:630-634. doi:10.1130/00917613(1978)6<630:PCOTIO > 2.0.CO;2

Lawrence, K.T.; Liu, Z.H. \& Herbert, T.D. 2006. Evolution of the eastern tropical Pacific through Plio-Pleistocene glaciation. Science, 312:79-83. doi:10.1126/science.1120395

Lezaud, L. 1968. Espèces nouvelles de nannofossiles calcaires (Coccolithopohridés) d'Aquitaine sud-ouest. Revue de Micropaleontologie, 2:22-28.

Locker, S. 1973. Coccolithineen aus dem Paläogen Mitteleuropas. Paläobotanik, 3:735-836.

Loeblich, A.R. \& Tappan, H. 1978. The coccolithophorid genus Calcidiscus Kamptner and its synonyms. Journal of Paleontology, 52:1390-1392.

Lohmann, H. 1902. Die Coccolithophoridae, eine Monographie der Coccolithen bildenden Flagellaten, zugleich ein Beitrag zur Kenntnis des Mittelmeerauftriebs. Aschiv für Protistenkunde, 1:89-165.

Martín-Barajas, A.; Vázquez-Hernández, S.; Carreño, A.L.; Helenes, J.; Suárez-Vidal, F. \& Álvarez-Rosales, J. 2001. Late Neogene Stratigraphy and tectonic control on facies evolution in the Laguna Salada Basin, Northern Baja California, Mexico. Sedimentary Geology, 144:5-35. doi:10.1016/S0037-0738(01)00133-6

Martini, E. 1969. Calcareous nannofossils from the Kallo well. Mémoire Explication Cartes géologique Miniere Belge, 11:39-41.

Martini, E. 1971. Standard Tertiary and Quaternary calcareous nannofossils zonation. In: PLANKTONIC CONFERENCE, 2, 1970. Proceedings, Rome, Tecnoziencia, p. 737-785.
Martini, E. \& Worsley, T. 1971. Tertiary calcareous nannofossils from the western equatorial Pacific. In: E.L. Winterer; W.R. Riedel; P. Brönnimann; E.L. Gealy; G.R. Heath; L. Kroenke; E.R. Martini Jr.; J. Resig \& T. Worsley (eds.) Deep Sea Drilling Project, Washington, DSDP, p. 1471-1507 (Initial Reports 7). doi:10.2973/dsdp.proc.7.129.1971

McCloy, C.; Ingle, J.C. \& Barron, J.A. 1988. Neogene stratigraphy, foraminifera, diatoms, and depositional history of Maria Madre Island, Mexico: evidence of early Neogene marine conditions in the southern Gulf of California. Marine Micropaleontology, 13:193-212. doi:10.1016/0377-8398(88)90003-5

McDougall, K. 2008. Late Neogene marine incursions and the ancestral Gulf of California. In: M.C. Reheis; R. Hershler \& D.M. Miller (eds.) Late Cenozoic drainage history of the southwestern Great Basin and lower Colorado river region: geologic and biotic perspectives, Boulder, The Geological Society of America, p. 355-373 (Special papers 439). doi:10.1130/2008.2439(16)

Müller, C. 1974. Calcareous nannofossils, Leg 25 (Western Indian Ocean). In: P.R. Supko; K. Perch-Nielsen \& R.L. Carlson (eds.) Deep Sea Drilling Project, Washington, DSDP, p. 579-633 (Initial Reports 25).

Murray, G. \& Blackman, V.H. 1898. On the nature of the Coccospheres and Rhabdospheres. Philosophical Transactions of the Royal Society of London, 190:427-441.

Nishida, S. 1971. Nannofossils from Japan IV. Calcareous nannofossils fossils from the Tonohama Group, Shikoki, southwest Japan. Transactions and Proceedings of the Palaeontological Society of Japan, 83:143-161.

Okada, H. \& Bukry, D. 1980. Supplementary modification and introduction of code number to the low-latitude coccolith biostratigraphic zonation (Bukry, 1973; 1975). Marine Micropaleontology, 5:321-325. doi:10.1016/03778398(80)90016-X

Okada, H. \& Honjo, S. 1973. The distribution of oceanic coccolithophores in the Pacific. Deep-Sea Research, 20:355-374. doi:10.1016/0011-7471(73)90059-4

Okada, H. \& Mclntyre, A. 1979. Seasonal distribution of the modern Coccolithophores in the western North Atlantic Ocean. Marine Biology, 54:319-328. doi:10.1007/BF00395438

Pagani, M.; Liu, Z.; LaRiviere, J. \& Ravelo, A.C. 2010. High Earth-system climate sensitivity determined from Pliocene carbon dioxide concentrations. Nature Geoscience, 3:27-30. doi:10.1038/ngeo724

Parente. A.; Cachão, M.; Karl-Heinz, B.; Abreu, L. \& Ferreira, J. 2004. Morphometry of Coccolithus pelagicus s.l. (Coccolithophore, Haptophyta) from offshore Portugal, during the last $200 \mathrm{kyr}$. Micropaleontology, 50:107-120. doi:10.2113/50.Suppl_1.107

Perch-Nielsen, K. 1977. Albian to Pleistocene calcareous nannofossils from the western south Atlantic, DSDP Leg 39. In: P.R. Supko; K. Perch-Nielsen \& R.L. Carlson (eds.) Deep Sea Drilling Project, Washington, DSDP, p. 699-823 (Initial Reports 39). doi:10.2973/dsdp.proc.39.131.1977

Perch-Nielsen, K. 1985. Cenozoic calcareous nannofossils. In: H.M. Bolli; J.B. Saunders \& K. Perch-Nielsen (eds.) Plankton Stratigraphy, Cambridge University Press, p. 427-554

Piña-Arce, M. 2010. Bioestratigrafía con nannofósiles calcáreos en el área de Rancho Algodones, Baja California Sur. Universidad Autónoma de Baja California Sur, Undergraduate Thesis, 60 p.

Pujos, A. 1987. Mise en place de la circulation au Pacifique central equatorial et des assemblages des nannofossiles calcaires au Neogene (Leg DSDP 85); II, Influence de l'emersion de l'isthme de Panama, entre 7 et $2 \mathrm{Ma}$. Bulletin de la Société Géologique de France, 3:731-736. 
Puy-Alquiza, M.I. 1992. Geología de la isla San José, Canal San José y su posible correspondencia con el Macizo Peninsular. Universidad Autónoma de Baja California Sur, Undergraduate Thesis, $164 \mathrm{p}$.

Rade, J. 1975. Scyphosphaera evolutionary trends with special reference to Eastern Australia. Micropaleontology, 21:151-165.

Ravelo, A.C.; Andreasen, D.H.; Lyle, M.; Lyle, A.O. \& Wara, M.W. 2004. Regional climate shifts caused by gradual global cooling in the Pliocene epoch. Nature, 429:263-267. doi:10.1038/ nature 02567

Rio, D. 1982. The fossil distribution of Coccolithophore genus Gephyrocapsa Kamptner and related Plio-Pleistocene chronostratigraphic problems. In: W.L. Prell et al. (eds.) Deep Sea Drilling Project, Washington, DSDP, p. 325-343 (Initial Reports 68). doi:10.2973/dsdp.proc.68.109.1982

Roth, P.H. 1970. Oligocene calcareous nannofossils biostratigraphy. Eclogae Geologicae Helvetiae, 63:799-881.

Sáez, A.G.; Probert, I.; Geisen, M.; Quinn, P.; Young, J.R. \& Medlin, L.K. 2003. Pseudo-cryptic speciation in coccolithophores. Proceedings of the National Academy of Science of the United States of America, 100:7163-7168. doi:10.1073/ pnas. 1132069100

Schiller, J. 1925. Die planktonischen Vegetationen des adriatischen Meeres. A. Die Coccolithophoriden-Vegetation in den Jahren 1911-14. Archiv für Protistenkunde, 51:1-130.

Schiller, J. 1930. Coccolithineae. In: J. Rabenhorst (ed.) Kryptogamen-Flora von Deutschland, Österreich und der Schweiz, Akademische Verlagsgesellschaft, p. 89-267

Seki, O.; Foster, G.L; Schmidt, D.N; Mackensen, A.; Kawamura, K. \& Pancost, R.D. 2010. Alkenone and boron based Oligocene $p \mathrm{CO}_{2}$ records. PANGAEA. doi:10.1594/PANGAEA. 732923

Sherwood, W.W. et al. 2002. The Nanno-Ware Database version 2002.12. Chapel Hill, International Nannofossils Association, CD-ROM 1.

Shiono, M. \& Koizumi, I. 2002. Taxonomy of the Azpetia nodulifera group in Late Neogene sediments from the northwest Pacific Ocean. Diatom Research, 17:337-362. doi:10.1080/026924 9X.2002.9705553

Sims, P.A.; Fryxell, G.A. \& Baldauf, J.G. 1989. Critical examination of the diatom genus Azpeita: species useful as stratigraphic markers for the Oligocene and Miocene epochs. Micropaleontology, 35:293-307.

Stainforth, R.M.; Lamb, J.L.; Luterbacher, H.; Beard, J.H. \& Jeffords, R.M. 1975. Cenozoic planktonic foraminiferal zonation and characteristics of index forms. Lawrence, University Kansas, 425 p. (Paleontological Contribution 62).

Stradner, H. 1961. Vorkommen von Nannofossilien im Mesozoikum und Alttertiän. Erdöl-Zeitschrift für Bohr-und Fördertechnik, 77:77-88.

Takayama, T. 1967. First report on nannofossils of the Upper Tertiary and Quaternary of the southern Kwanto region, Japan. Jahrbuch der Geologischen Bundesanstalt Wien, 110:169-198.

Takayama, T. \& Sato, T. 1987. Coccolith biostratigraphy of the North Atlantic Ocean, Deep Sea Drilling Project Leg 94. In: W.F. Ruddiman et al. (eds.) Deep Sea Drilling Project, Washington, DSDP, p. 651-702 (Initial Reports 94). doi:10.2973/dsdp. proc. 94.113 .1987

Tan, S.H. 1927. Discoasteridae Incertae sedis. Proceedings of the Koninklijke Nederlandse Akademie van Wetenschappen, 30:411-419.

Theodoridis, S. 1984. Calcareous nannofossil biostratigraphy of the Miocene and revision of the helicoliths and discoasters. Utrecht Micropaleontological Bulletin, 32:1-271.
Umhoefer, P.J.; Schwennicke, T.; Del Margo, M.T.; Ruiz-Geraldo, G.; Ingle, J.C. \& McIntosh, W. 2007. Transtensional faulttermination basins: an important basin type illustrated by the Pliocene San José Island basin and related basins in the southern Gulf of California, Mexico. Basin Research, 19:297-322. doi:10.1111/j.1365-2117.2007.00323.x

Young, J.R. 1998. Neogene. In: P.R. Bown (ed.) Calcareous nannofossil biostratigraphy, Chapman \& Hall, p. 225-265.

Young, J.R. \& Bown, P.R. 1997. Higher classification of the calcareous nannofossil. Journal of Nannofossils Research, 19:15-20.

Young, J.R.; Bown, P.R \& Lees, J.A. 2014. Nannotax3. Chapel Hill, International Nannofossils Association. Available at http://www. mikrotax.org/Nannotax3/; accessed on 12/14/2018.

Varol, O. 1982. Calcareous nannofossils from the Antalya Basin, Turkey. Neues Jahrbuch für Geologie und Paläontologie Monatshefte, 4:244-256.

Varol, O. 1984. New Neogene calcareous nannofossil taxa from Malta and southern Turkey. Neues Jahrbuch für Geologie und Paläontologie Monatshefte, 6:375-384.

Vázquez-Hernández, S.; Carreño, A.L. \& Martín-Barajas, A. 1996. Stratigraphy and paleoenvironments of the Mio-Pliocene Imperial Formation in the Eastern Laguna Salada area, Baja California, Mexico. In: P. Abbot \& J. Cooper (eds) Field Conference Guide 1996 for the American Association of Petroleum Geologists, Tulsa, Society for Sedimentary Geology, p. 373-380 (Book 80).

Wade, B.S. \& Bown, P.R. 2006. Calcareous nannofossils in extreme environments: the Messinian Salinity Crisis, Polemi Basin, Cyprus. Palaeogeography, Palaeoclimatology, Palaeoecology, 233:271-286. doi:10.1016/j.palaeo.2005.10.007

Wallich, G.C. 1877. Observations on the coccosphere. Annals and Magazine of Natural History, 19:342-350.

Wara, M.W.; Ravelo, A.C. \& Delaney, M.L. 2005. Permanent El Niño-like conditions during the Pliocene warm period. Science, 309:758-761. doi:10.1126/science. 1112596

Weber-van Bosse, A. 1901. Études sur les algues de 1'Archipel Malaisien III. Note préliminaire sur les résultats algologíques de l'expédition du Siboga. Annales du Jardin Botanique de Buitenzorg, 17:126-141.

Wei, W. \& Wise Jr., S.W. 1990. Biogeographic gradients of middle Eocene-Oligocene calcareous nannofossils in the South Atlantic Ocean. Palaeogeography, Palaeoclimatolology, Palaeoecology, 79:29-61. doi:10.1016/0031-0182(90)90104-F

Winter A.; Jordan R.A. \& Roth, P. 1994.Biogeography of living coccolithophores in ocean waters. In: A. Winter \& W.G. Sieser (eds.) Coccolithophores, Cambridge University Press, p. 161-177.

Wise, S.W. 1973. Calcareous nannofossils from cores recovered during Leg 18, Deep Sea Drilling Project: biostratigraphy and observations on diagenesis. In: D. LaVerne et al. (eds.) Deep Sea Drilling Project, Washington, DSDP, p. 569-615 (Initial Reports 18). doi:10.2973/dsdp.proc.18.115.1973

Received in 23 April 2018; Accepted in 13 December 2018. 
Appendix 1. Check list and consensual stratigraphic ranges of species of calcareous nannofossils recorded in two sedimentary columns measures un the Palma Sola Basin, San José Island, Baja California Sur.

Braarudosphaera bigelowii (Gran \& Braarud, 1935) Deflandre, 1947 (100.5-0.0 Ma)

Calcidiscus leptoporus (Murra \& Blackman, 1898) Loeblich \& Tappan, 1978 (22.8-0.0 Ma)

Calcidiscus macintyrei (Bukry \& Bramlette, 1969) Loeblich \& Tappan, 1978 (2.4-0.4 Ma)

Ceratolithus cristatus Kamptner, 1950 (5.1-1.7 Ma)

Coccolithus pelagicus (Wallich, 1877) Schiller, 1930 (66.0-0.0 Ma)

Coccolithus pliopelagicus Wise, 1973 (57.2-42.8 Ma)

Coccolithus streckeri Takayama \& Sato, 1987 (15.6-0 Ma)

Coronocyclus nitescens (Kamptner, 1963) Bramlette \& Wilcoxon (46.29-11.9 Ma)

Discoaster brouweri Tan, 1927 emend. Bramlette \& Riedel, 1954 (10.5-1.9 Ma)

Discoaster formosus Martini \& Worsley, 1971 (15.6-13.5 Ma)

Discoaster pentaradiatus Tan, 1927 (8.2-5.5 Ma)

Discosphaera sp. Haeckel, 1894 (23.0-0.0 Ma)

Gephyrocapsa small (4.1-0.02 Ma)

Gephyrocapsa aperta (4.1-0.02 Ma)

Gephyrocapsa margereli Brèhéret, 1978 (4.1-0.02 Ma)

Gephyrocapsa proto huxleyi McIntyre, 1970 (4.7-0-0 Ma)

Hayaster perplexus (Bramlette \& Riedel, 1954) Bukry, 1973 (57.2-0.0 Ma)

Hayella sp. Gartner, 1969 (49.1-5.1 Ma)

Helicosphaera ampliaperta Bramlette \& Wilcoxon, 1967 (22.8-14.9 Ma)

Helicosphaera burkei Black, 1971 (15.6-8.6 Ma)

Helicosphaera carteri (Wallich, 1877) Kamptner, 1954 (23.1-0.0 Ma)

Helicosphaera selli(Bukry \& Bramlette, 1969) Jafar \& Martini, 1975 (5.5-0.4 Ma)

Holodiscolithus macroporus (Deflandre in Deflandre \& Fert, 1954) Roth, $1970(57.21-0.29 \mathrm{Ma})$

Oolithotus sp. Cohen \& Reinhardt, 1968 (23.0-0.0Ma)

Pontosphaera callosa (Martini, 1969) Varol, 1982 (15.6-2.0 Ma)

Pontosphaera discopora Schiller, 1925 (23.0-0.0 Ma)
Pontosphaera var. japonica (Takayama, 1967) Nishida, 1971(23.0-0.0 Ma)

Pontosphaera multipora (Kamptner, 1948) Roth, 1970 (66.0-0.0 Ma)

Pseudoemiliania lacunosa (Kamptner, 1963) Gartner, 1969 (3.9-0.4 Ma)

Pseudoemiliania ovata (Bukry, 1973) Young, 1998 (4.1-0.4 Ma)

Reticulofenestra haqii Backman, 1978(22.8-3.7 Ma)

Reticuofenestra minuta Roth, 1970 (50.5-2.5 Ma)

Reticulofenestra minutula (Gartner, 1967) Haq \& Berggren, 1978 (3.9-1.9 Ma)

Reticulofenestra rotaria Theodoris, 1984 (7.4-6.9 Ma)

Reticulofenestra sp. Hay, Mohler \& Wade, 1966 (55.9-0.0 Ma)

Scyphosphaera apsteinii Lohmann, 1902 (53.7-0.0 Ma)

Scyphosphaera biarritzensis Lezaud, 1968 (53.7-0.0 Ma)

Scyphosphaera brevisa Varol, 1984 (14.8-1.0 Ma)

Scyphosphaera campanula Deflandre, 1942 (14.8-2.0 Ma)

Scyphosphaera darraghi Rade, 1975 (14.8-2.2 Ma)

Scyphosphaera gladstonensis Rade, 1975 (5.6-1.0Ma)

Scyphosphaera globulata Bukry \& Percival, 1971(8.2-1.9 Ma)

Scyphosphaera halldali Deflandre, 1954 (8.6-5.2 Ma)

Scyphosphaera kamptneri Muller, 1974 (8.6-2.0Ma)

Scyphosphaera pacifica Rade, 1975 (5.8-1.0 Ma)

Scyphosphaera penna Kamptner, 1955 (10.6-2.8 Ma)

Scyphosphaera pulcherrima Deflandre, 1942 (13.5-0.4 Ma)

Scyphosphaera recta (Deflandre) Kamptner, 1955 (10.6-1.8 Ma)

Scyphosphaera recurvata Deflandre, 1942 (32.3-0.6 Ma)

Scyphosphaera aff. Rottiensis Jafar, 1975 (10.6-1.8 Ma)

Syracosphaera histrica Kamptner, 1941 (2.5-0.0 Ma)

Syracosphaera pulchra Lohmann, 1902 (5.3-0.0 Ma)

Thoracosphaera fossata Jafar, 1975 (23.9-5.6 Ma)

Thoracosphaera sáxea Stradner, 1961 (62.0-0.0 Ma)

Umbilicosphaera foliosa (Kamptneri, 1963, ex Kleijne, 1993) Geisen in Sáez et. al., 2003 (3.7-0.0 Ma)

Umbilicosphaera sibogae (Weber-van Bosse) Gaarder 1970 (3.92-0.0 Ma) 